\title{
Integrating Geomorphological Data, Geochronology, and Ar- chaeological Evidence for Coastal Landscape Reconstruction. The Case of Ammoudara Beach, Crete
}

\author{
George Alexandrakis ${ }^{1 *}$, Stelios Petrakis 11 and Nikolaos A. Kampanis ${ }^{1}$
}

${ }^{1}$ Coastal and Marine Research Lab, Institute of Applied \& Computational Mathematics, Foundation for Re-
search \& Technology-Hellas
${ }^{*}$ Correnspondence: alexandrakis@iacm.forth.gr

Abstract: Understanding the processes that govern the transformation of the landscape through time is essential for exploring the evolution of a coastal area. Coastal landscapes are dynamic sites, with their evolution strongly linked with waves and sea-level variations. Geomorphological features in the coastal area, such as beachrock formations and dune fields, can function as indicators of the coastal landscape evolution through time. However, our knowledge of the chronological framework of coastal deposits in the Aegean coasts is limited. Optically stimulated luminescence dating techniques are deemed to be very promising in direct dating of the coastal sediments, especially when they are linked with archaeological evidence. The dating of the sediments from different sediment core depths, as they are determined by the method of luminosity, allow us to calculate the rate of sediment deposition over time. Additionally, the coastal evolution and stability was studied from 1945 until today, with the use of aerial photographs and satellite images. This paper presents the 6000 ka years evolution of a coastal landscape based on geomorphological, archaeological, and radio-chronological data. Based on the results, the early stages of the Ammoudara beach dune field appears to be formed $\sim 9.0-9.6 \mathrm{ka} \mathrm{BP}$, while the OSL ages from $6 \mathrm{~m}$ depth represented the timing of its stabilization (OSL ages $\sim 5-6 \mathrm{ka}$ ). This indicates that the dune field appears to already have been formed long before the Bronze Age (5-10 ka BP) and became stabilized with only localized episodes of dune reactivation occurring, while high coastal erosion rates are found in modern times.

Keywords: Sea level changes; Luminescence dating; coastal archaeology; landscape reconstruction; Bronze age; Crete

\section{Introduction}

Understanding and modelling the geomorphological and depositional processes, resulting to the transformation of the landscape in a diachronic perspective, is essential for exploring the cultural biography of a coastal area. Coastal landscapes are dynamic landscapes, with their evolution to be strongly linked with waves and sea level variations. There are several difficulties in studying the cultural landscape of coastal areas. In terms of environmental change, they are principally related to their dynamic character. Wave and wind action result in processes like coastal erosion and formation of coastal dunes. Coastal erosion often leads to an irreparable loss of information used in the identification of maritime structures and activities. The Mediterranean, as a major example of a strictly coastal related inhabited area since the ancient times, is a hotspot of both opportunity and concern. Consequently, these changes in the coastline can generate new social relations as newly formed areas can be suitable for agriculture or already inhabited ones be abandoned due to flood by sea wate [1].

Sea level changes are divided into two categories, those related to global climate change and modern. The former lasts hundreds of thousands of years, while the latter lasts from hours to years. Relative changes in sea level are the results of climatic factors 
but also tectonic movements. In terms of global eustatism, the Mediterranean average sea level at the end of the last glacial period, during the Last Glacial Maximum (18 ka - $21 \mathrm{ka}$ years before present BP) was 110-130 m lower than today [2-4] which is supported also by most of the other curves of global ocean changes [5]. Furthermore, it is also accepted that the process of glacio-eustasy has been completed approximately 6,000 radiocarbon years BP [6]. This period (from approx. $20 \mathrm{ka}$ to $7 \mathrm{ka} \mathrm{BP}$ ) is associated with a phase of rapid sea-level rise. Then began the last interglacial period continued to this day, during which the sea level rises, following the temperature rise. This period is characterized by two main phases: (a) the phase of rapid ascent at a rate of about $1 \mathrm{~cm} /$ year, which was completed 6,000-7,000 years ago; and (b) the phase of slow rise at a rate of $\sim 1 \mathrm{~mm} /$ year [7], which continues to this day, according to instrumental measurements [8,9], a fact attributed to climate change and the greenhouse effect [10]. This has two main consequences for the case of the Mediterranean Sea, firstly the eustatic component of sea-level rise since the Roman Period along the Tyrrhenian coast of Italy (Central Mediterranean) has been $1.25 \pm 0.25$ meters and, secondly, the onset of modern relative sea-level rise $(0.13 \pm 0.09 \mathrm{~m})$ has occurred at approximately $100 \pm 53$ years before present (late 19th century or early 20 th century) [11]. From 11,500 to about 6,000 years BP, the sea level recorded a rapid rise, due to glacial factors, reaching at about $5 \pm 1 \mathrm{~m}$ lower than today. As recent studies on the Aegean Sea have shown $[8,12,13]$, over the last 5,000 years the change in sea level follows a steady rate of increase, about $0.9 \mathrm{~mm} /$ year, reaching at 2,000 BP about $1-2 \mathrm{~m}$ lower than the current level. The relative rates of sea level rise during the Holocene differ from region to region in Greece, due to local tectonic activity. Thus, in southern Evia, the rate of sea level rise for the period between 8,000- and 6,000-years BP was of the order of 8.5 $\mathrm{mm} /$ year [14,15], on the Central Greece coast $12.3 \mathrm{~mm} /$ year [16], in the Peloponnese region, excluding the very tectonically active Corinthian Gulf, $6 \mathrm{~mm} /$ year [17]. Over the last 6 thousand years, the rate of increase of the level decreases to about $0.9-1 \mathrm{~mm} /$ year, as shown by data from the Peloponnese [17], the island of Skyros [14] and central Greece [16]. Regarding the modern changes of the sea level, measurements in the period 1890 1990 show that the average sea level in Central Crete, has risen by $18 \mathrm{~cm}(\mathrm{~min}:+10 \mathrm{~cm}$, max: $+25 \mathrm{~cm})$, an increase corresponding to an average rate of $1.8 \mathrm{~mm} / \mathrm{a}$ [18].

The island of Crete is located along the transition zone between the African and Eurasian plates, in the fore arc of the Hellenic Subduction Zone. Differential tectonic behavior is observed in the continental area of Crete. Compression prevails in western Crete, while tectonic extension dominates in eastern Crete [19-24]. By the late Upper Miocene to early Pliocene, the conditions of deposition changed from open sea into coastal or subaerial environment $[25,26]$. The island uplifted gradually during Quaternary, as evidenced by marine Pleistocene terraces and coastal deposits formed during the corresponding interglacial stages [22,27-32].

The analysis of the tectonic faults in the area has shown that from the Middle Miocene until the present, the tectonic development of the Heraklion basin has been mainly the result of successive extensional periods that generated at least three faults. The first, consisting of east-west trending faults, was probably initiated in the Early Miocene. However, the most extensive activation of these faults took place during the Middle/Late Miocene until the early Messinian, due to the southwards roll-back of the subduction zone. The established north-south extensional regime created the first east-west trending basins in Crete [33]. While the north coast of the island appears to be stable after AD 365 earthquake event [34], when vertical movements in the area reached -1 m [35] (Fig. 1) 


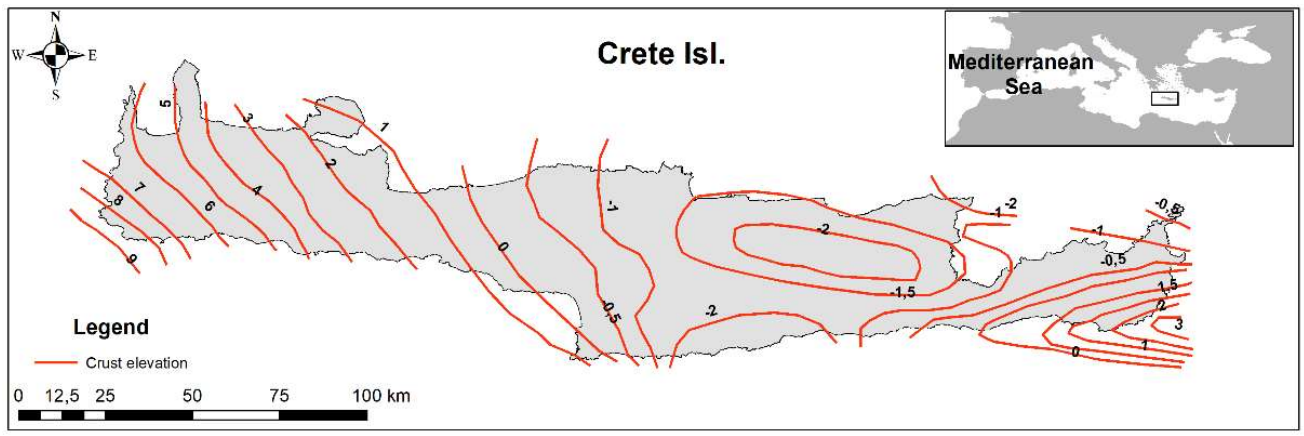

Figure 1. Tectonic uplift after the AD 365 Earthquake (modified from [35]).

Moreover, the eruption of Santorini in the Late Bronze Age resulted in tsunami waves, based on the evidence of tsunami deposits along coastal areas of Greece [36,37]. Numerical models have shown that tsunami wave amplitudes were significant with inland inundation of up to $200 \mathrm{~m}$. along the coast of Crete [38]. Additionally, evidence from the $\mathrm{AD} 365$ earthquake, the largest known seismic event in the Eastern Mediterranean, supports the idea that the respective tsunami reached not only the NW part of Crete but also severely affected the inhabited coastal areas in Heraklion [39].

Coastlines in Greece are generally in a state of constant erosion due to anthropogenic interventions and climate change. Studies for the area [40,41] estimate that about $25 \%$ of the Aegean coast consists mainly of coastal zones and low-lying coasts and deltas in a state of erosion. The northern coastline of Crete experiences extensive erosion, one with the highest severity in Greece, which affects $65.8 \%$ of its coastal zones. This large percentage of erosion is mainly due to the presence of extensive coastal zones with generally low beach slope, thus more vulnerable to erosion and the high frequency of large waves created by north and northeast winds in the Aegean [42].

Beachrock formations come from the rapid cohesiveness of coastal loose sediments (sands, gravels) in the inland beach area. The adhesive material $\left(\mathrm{CaCO}_{3}\right)$ can be calcitic, aragonitic, or both and comes from chemical processes related to seawater and / or meteoric fresh water. The welding process takes place either superficially and / or under a thin layer of sediments in the subtidal zone and includes sediments of various diameters and of classical and / or biogenic origin [43-45]. The dimensions of the beach rocks range from a few meters to a few kilometres in length, width from less than one meter to $300-400 \mathrm{~m}$ and thickness from 0.3 to $3 \mathrm{~m}$. These formations present flat layers that slope towards the sea, either with the general slope of the beach [46], or with a greater slope than that of the rest of the beach [47-49]. Appearances have been reported on many coasts of the world [49-52], and in Greece [53-55]. Beach rocks, due to their ability to form in the tidal zone, are considered indicators of old coastlines and are often used, as a fully accepted and valid method by the scientific community, in research to detect sea level changes in earlier periods [51,55-58]. The determination of the age and position of the respective past coastline and the corresponding sea level by using of the depth of occurrence of a beachrock formation and its age, by stratigraphic or radio-chronological methods, are now widely used [59-62]. On the opposite, aeolianite is any rock formed by the lithification of sediment deposited by aeolian processes. Coastal aeolianites are usually coastal formations consisting of carbonate sediment of shallow marine biogenic origin, formed into coastal dunes by the wind, and subsequently lithified [63]. Quaternary aeolianites are typically coastal deposits composed of fine to medium grained, well-sorted sand. The character of the sand grains depends much on the local environmental setting, although the dominant constituents of the aeolianites are quartz and feldspar grains and marine carbonate particles. Both the detrital mineral grains and the carbonate particles are often derived from local sources. Several studies have used dating methods to establish the time framework of aeolianites and beachrock formation and assess their connection with sea level changes [64- 
67]. Aeolianites are mainly considered to be deposited around the world at sea level high stands [68,69], but there are several recent studies indicate as a genetic mechanism for the formation and accumulation aeolian deposits the cold and low sea level scenario [70-77]. Differences in the timing of deposition and morphology of aeolian dunes during major sea level changes (high stands, low stands) among regions appear to be dependent on the interactions caused by minor-secondary sea level changes, local climatic conditions, sediment availability, and differences in the inland-near-shore topography [78]. However, our knowledge on the chronological framework of coastal deposits in the coasts of the Aegean is limited. Early studies on sedimentary deposits are found on raised marine terraces along the coasts of Crete which reveal the existence of characteristic Pleistocene marine fauna like Cantharus viverratus, Kien., Conus testudinarius Mart., Polinices lacteus Guild., Patella safiana, Lmk. and Strobus bubonius Lmk [79-83].

The coastal area of the Gazi-Ammoudara region, $8 \mathrm{~km}$ northwest of the palatial centre of Knossos and not far from the Psiloritis mountain region and the administrative Minoan centre of Tylissos is, archaeologically regarded, among the most poorly investigated areas, considering its proximity to some of the most important Minoan sites of Crete. This gap in archaeological research provides bias in regional and inter-regional archaeological interpretations and affects our understanding of the political, social, and economic networks in north-central Crete. Consequently, for heritage management, this gap is even more pronounced since the lack of data and the limited knowledge about existing archaeological sites and features implies difficulties in implementing effective strategies for their preservation. The archaeological importance of the region has been documented by early scholars [84,85]. Although several archaeological remains were destroyed by natural processes and modern human activity (agriculture, grazing and construction), evidence from rescue excavations, the surface remains and chance finds dating from the Neolithic to the Ottoman period were found in many parts of the area, suggesting intensive patterns of habitation and other human activity. However, the only excavation in the coastal zone was carried out in the late 1970s and revealed a building, which was only partially excavated (Fig. 2). It seems that it was a domestic unit, which most likely belonged to an extensive Neopalatial (MM III - LM IA) settlement that was part of the wider social contact network in the northern coastal zone of Minoan Crete. Pottery from the excavation is dated predominately to MM III - LM IA, though it includes Pre- and Post-palatial sherds $[86,87]$.

Luminescence measurements are most frequently carried out on the quartz-rich fraction of aeolian dune deposits [88-90]. Environments rich in coastal and wind sediments [91] such as loess formations and dunes [92] have been shown to be suitable materials for optically stimulated luminosity dating, as they have been adequately exposed to sunlight before their deposition. However, in other types of sedimentary environments where there is doubt about their adequate exposure to sunlight, an investigation of the "zeroing" of the original luminance signal is required. Following relatively recent applications of luminescence techniques in a variety of sedimentary environments [93], such as alluvial and colloquial sediments, glacial and peripheral deposits [94], riverbed sediments [95], sediments associated with cracks and seismicity [96,97] as well as terrace materials [98], these proved to be quite reliable, as ages were obtained which were in chronological agreement with the already existing reports. Optically Stimulated Luminescence (OSL) dating [99] has become a promising technique for dating fluvial, deltaic and coastal sediments [34,100-103]. The luminescence method takes advantage of the presence of radioactive isotope elements such as uranium (U), thorium (Th) and potassium (K) which are usually contained in common rocks for dating [104]. This stored energy of minerals is representative of their age and can be zeroed in two ways: either by heating the sample to a relatively high temperature $\left(>300^{\circ} \mathrm{C}\right)$, or by exposure to sunlight, which could occur during the processes of erosion and sediment transport [94]. Essentially, both processes release any pre-existing stored energy by setting the "clock" of sediment age to zero. Environments rich in coastal and wind sediments [88] such as loess formations and dunes 
[105] have been shown to be suitable materials for optically stimulated luminosity dating, as they have been adequately exposed to sunlight before their deposition. However, in other types of sedimentary environments where there is doubt about their adequate exposure to sunlight, an investigation of the "zeroing" of the original luminance signal is required. Following relatively recent applications of luminescence techniques in a variety of sedimentary environments [93], such as alluvial and colloquial sediments, glacial and peripheral deposits [94], riverbed sediments [95], sediments associated with cracks and seismicity [96,97] as well as terrace materials [98], these proved to be quite reliable, as the obtained ages were in chronological agreement with the already existing reports.-Thus, the Luminosity method is preferred as the most appropriate for investigating the location of the coastline [102,106-109]. The ages of the sediments from different depths, as they are determined by the method of luminosity, allow us to calculate the rate of sediment deposition over time, and therefore the advance or erosion of an area such as the area of Ammoudara. This paper presents the evolution of a coastal environment based on geomorphological, archaeological, and radio-chronological data that provided the reconstruction of the coastal area of Ammoudara beach in northern Crete during Bronze Age

\section{Study area}

The coastal area of Ammoudara (Fig. 2) is located on the northern coast of Crete Island, approximately $2 \mathrm{~km}$ to the west of the city of Heraklion, Crete, Greece. The area is an alluvial plain and is characterised by low-lying regions, some parts of which have elevations either close or even below the mean sea level. The entire coastal area is shaped by significant geomorphological and tectonic processes as well as human activity [110]. The total coastline length is approximately $8 \mathrm{~km}$, with a W to E trending, being slightly curved and having a sub-aerial width of up to $60 \mathrm{~m}$. The beach is backed by a narrow dune field; the dunes do not exceed $3 \mathrm{~m}$ in height and most of the dune fields have been destroyed by anthropogenic activities. Three small rivers, Gazanos (catchment area $192 \mathrm{~km}^{2}$ ), Xiropotamos (c.a. $35 \mathrm{~km}^{2}$ ) and Giofiros (c.a. $279 \mathrm{~km}^{2}$ ), discharge along the shoreline. At the west end of the beach, the Almiros stream drains the homonymous karstic spring (Fig. 2). The Ammoudara coastal zone is microtidal with an astronomical tidal range of less than $10 \mathrm{~cm}$ [111], while the tide gauge installed in the harbour of Heraklion has recorded sea level fluctuations of more than $1 \mathrm{~m}$ over the period 1984-2020; these fluctuations incorporate the effects of astronomical tides and meteorological forcing. The Ammoudara beach zone is exposed primarily to NW, N and NE wind-induced waves, with the NW directions being most frequent on an annual basis $(23.6 \%)$, followed by the NW $(12.4 \%)$ and the NE (3.7\%). Wave heights are usually smaller than $2 \mathrm{~m}(88 \%)$, with $36 \%$ of them being less than $0.5 \mathrm{~m}$ and only $2 \%$ being over $4 \mathrm{~m}$, on an annual basis [112]. Likewise, $77.3 \%$ of the offshore wave periods are less than $5 \mathrm{~s}$, while periods larger than $11 \mathrm{~s}$ have an annual frequency of only $0.74 \%$. The maximum wave conditions are induced by NW and $\mathrm{N}$ winds, during January, and March, with mean annual occurrence frequency of $0.01 \%$ and $0.03 \%$ respectively. The maximum wave characteristics of the NW wind-induced waves are $2.3 \mathrm{~m} / 4.6 \mathrm{~s}$ and of the prevailing $\mathrm{N}$ waves $6 \mathrm{~m} / 11 \mathrm{~s}$ [113].

A significant for the evolution of the Ammoudara beach area characteristic underwater formation is a shallow submerged reef. The reef is $\sim 4 \mathrm{~km}$ long, has a mean width of around $35 \mathrm{~m}$, while its rather planar crest lies, on average, at $0.6 \mathrm{~m}$ below the sea surface. Water depths exceed $3 \mathrm{~m}$ at its seaward side, while they are less than $2 \mathrm{~m}$ at its landward side. Previous studies in the area [113] have concluded that the reef represents a submerged beach rock formation, initially formed concurrently with the beach rocks along the western part of the present beach, based on the morphological and sedimentological characteristics of the reef. The reef consists of two distinct sedimentary layers: the upper layer, $0.3-\mathrm{m}$ thick, consisting of coarse-grained beach material having beach rock morphological characteristics (e.g., runnels, potholes, and grooves), and the lower layer, with thickness more than $0.5 \mathrm{~m}$, which consists of fine-grained sandy material with cross bedding. The coastal zone of Ammoudara Beach can be subdivided into two sectors based 
on the presence or absence of the reef: the western sector, where the reef is absent, and the eastern sector, which is characterized by the continuous presence of the reef at less than $40 \mathrm{~m}$ from the shoreline.
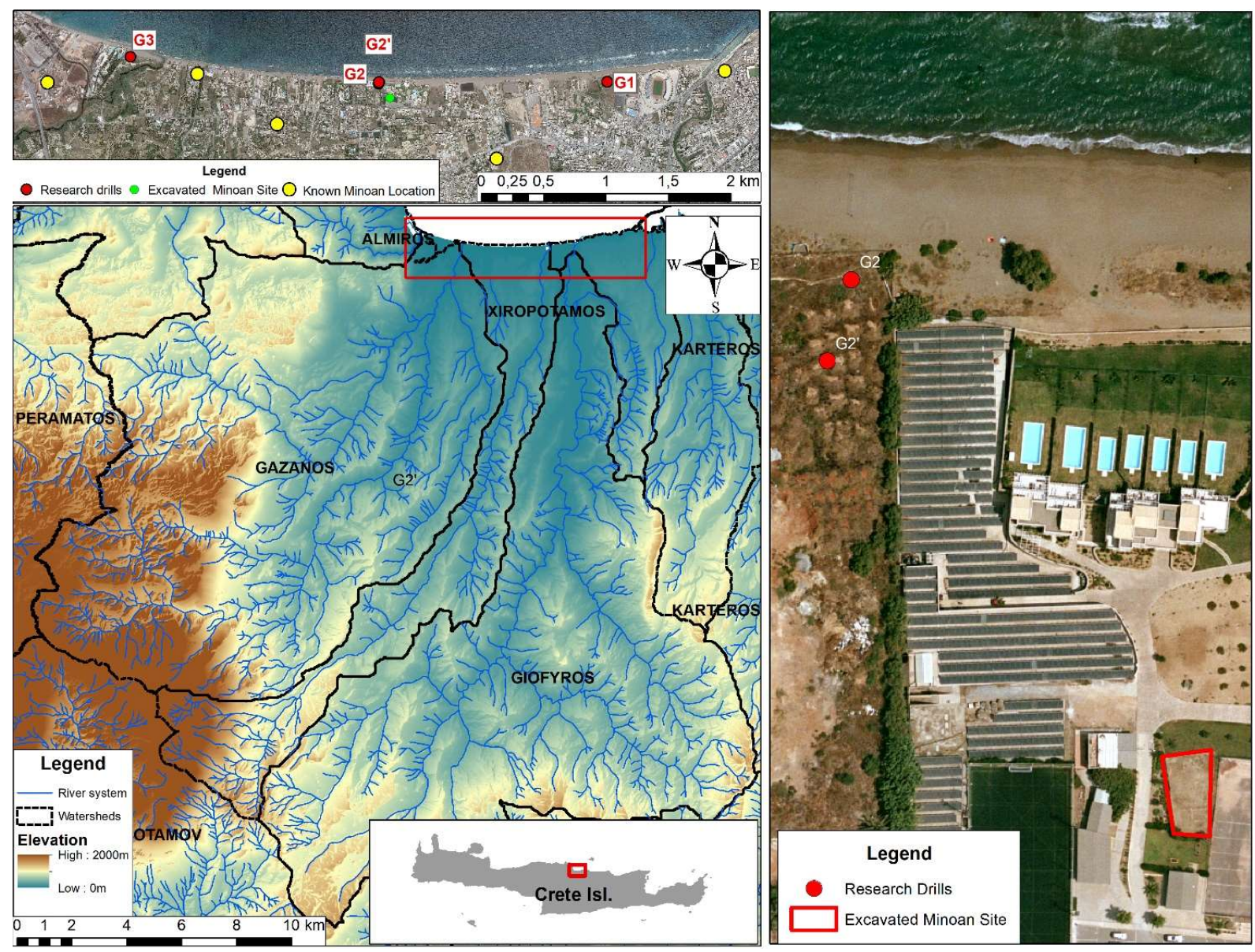

Figure 2. Location of area and hydrological Basins in the study area. Known Minoan sites, excavated Minoan site, and research drill positions. Hydrological basins, digital image and elevation provided by a $0.5 \mathrm{~m}$ DEM from Ktimatologio S.A.

\section{Materials and Methods}

Geomorphological and sedimentological mapping of the area was conducted with the use of satellite images, drone imagery and field surveys. For the geomorphological mapping, topographic diagrams from the Hellenic Army Geographical Service and Sentinel satellite images were used. The geomorphological surveys included elevation and slope measurements taken with the use of an RTK. Additionally, depth soundings were acquired with the use of a single beam echo-sounder reaching $20 \mathrm{~m}$ depth within the water, that were synthesized to create current bathymetry and beach elevations. Furthermore, surficial sediment samples were collected along the beach and analysed according to Folk's procedure [114]. To determine the depositional environment of the coastal sediments, sediment samples from four 10m deep research drills were used (Fig. 2) at approximately $60 \mathrm{~m}$ from the shoreline. From the resulting stratigraphic sections, the different sedimentary horizons were studied macroscopically, the sedimentary samples were collected, and the organisms found within them were identified to determine the deposition environment. For the OLS dating samples, lightproof plastic tubes were used, to avoid light contamination. 


\subsection{Optically stimulated luminescence (OSL)}

Dating and radioactivity measurements were implemented in twelve core samples by using OSL and Equilivient Doses calculations (for locations and depth of the samples see figure 2 and stratigraphy figure 6). For the radioactivity estimations, the top layer (2$4 \mathrm{~cm}$ ) of the core samples were used, the $4-8 \mathrm{~cm}$ of the inner part of the core was collected, dried at 50 $\mathrm{C}$ and passed through sieves sequentially decreasing mesh 150-125-100-63 $\mu \mathrm{m}$. Grain sizes from 100-150 $\mu \mathrm{m}$ were chemically treated for quartz purification. Parts of the samples used for radioactivity assessment were dried at $105^{\circ} \mathrm{C}$ for $24 \mathrm{~h}$ and passed through a $500 \mu \mathrm{m}$ mesh sieve. About $60-70 \mathrm{~g}$ of this sieved material were sealed in plastic containers and kept for radon equilibrium for a month. Afterward, the containers were measured for natural radioactivity. For chemical pre-treatment, small parts of portions of grain size $100-150 \mu \mathrm{m}$ of the samples were placed in separate plastic tubes. All samples were treated successively with $\mathrm{HCl}(8 \% \mathrm{w} / \mathrm{w})$ to remove carbonates, $\mathrm{H}_{2} \mathrm{O}_{2}(30 \% \mathrm{w} / \mathrm{w}$ organic residuals and HF $(40 \% \mathrm{w} / \mathrm{w})$, feldspars and etch off the outer parts of the quartz grains. Between chemical treatments, several water washes were performed.

\subsection{OSL measurements and equivalent dose (EDs) calculations}

Purified quartz grains (aliquots) were placed on small stainless disks for luminescence measurements. Typically, eighteen (18) disks in total were used for each sample. The SAR protocol was followed $[89,115]$ and paleodoses were measured after IR and blue-OSL signal recording. The IR protocol was used to check for feldspar impurities. Successive increasing doses were induced on disks to obtain "dose response curves" and the same protocol was used for these doses as described for natural ones. To eliminate sensitivity differences of the aliquots, the same dose was induced, referred as test dose, and the ratios of dose to test dose signals were used to obtain the "dose-response curves". Recycling and recuperation tests as well as dose recovery tests were performed for quality assurance. All measurements were performed in the Archaeometry Center of the University of Ioannina. Approximately $100 \mathrm{~g}$ of dried material was ground to powder and sieved through a $500 \mu \mathrm{m}$ mesh sieve at $105^{\circ} \mathrm{C}$ until constant weight. About $60-70 \mathrm{~g}$ of each sample were put in a plastic container of standard geometry and were hermetically closed with a silicone sealant. The samples could reach the equilibrium of radon daughters (for about a month) and were measured for natural radioactivity. The age of a sample is calculated in terms of the equivalent dose ratio or Dose Rate (Gy) based on the following equation [116]. The equivalent dose is the total accumulated radioactivity to which the precipitate was exposed during the time it was deposited and in the laboratory is called Paleodose (De) [116]. The unit of measurement of absorbed radioactivity in the International System of Units (S.I) is Gray $(\mathrm{Gy})=>1 \mathrm{~Gy}=1 \mathrm{Joule} / \mathrm{kg}$. The Dose Rate is the rate at which natural radioactivity is absorbed by the crystalline granules per year. The age was calculated by the ratio equivalent dose (De) per Dose Rate [116].

\subsection{Coastline evolution}

Aerial photographs and satellite images were used to study the stability of the coastline and to measure its displacement over time. Based on these data, the coastlines were digitized with the utmost accuracy through ArcGIS 10.1 software, through which conclusions were drawn for the shoreline displacement over time. This was followed by processing with Digital Shoreline Analysis System DSAS v.5 [117] to quantify the changes. Three different types of remote sensing data were used for the identification of the beach areas alterations during the last 74 years. Historical analogue panchromatic aerial photographs, orthophotos and natural-colour satellite images. The acquisition of the aerial photographs took place during 1945, 1968, 1998 from Hellenic Military Geographical Service - HMGS, the orthophotos were acquired during 2005 and 2010 from Ktimatologio S.A, and the satellite images during 2009, 2012, 2013, 2016, 2017 and 2019 (Error! Reference source not found.). The aerial photos were scanned with a highresolution scanner (1200 dpi) and all image data was georeferenced in ArcGIS 10.1, using 
as reference dataset the 2010 Ktimatologio S.A. aerial photo, by using approximately 40 control points along the beach and 20 landmarks. All methodology was performed in WGS 84 / UTM zone 35N Reference System. The beach area and shorelines of the georeferenced images were manually digitized with the maximum accuracy, determined by each image's pixel size. The average accuracy of all images was about $0.5 \mathrm{~m}$. Transects perpendicular to the shoreline were created through DSAS with 50m interval. The statistic parameter extracted by the DSAS and presented in this work was the Net Shoreline Movement (NSM), which is the total distance between the earliest and most recent shorelines for each transect, in meters. Table 1 shows the date, type, scale and resolutions of each image used in the analysis.

Table 1: Date, type, scale, resolution and source of the images used for coastal evolution assessment

\begin{tabular}{ccccc}
\hline Date & Type & Scale & Pixel size & Source \\
\hline $17 / 09 / 1945$ & Aerial photo & $1: 42000$ & $3 \mathrm{~m}$ & HMGS \\
1968 & Aerial photo & $1: 15000$ & $1 \mathrm{~m}$ & HMGS \\
$23 / 07 / 1998$ & Aerial photo & $1: 10000$ & $1 \mathrm{~m}$ & HMGS \\
2005 & Orthophoto & $1: 15000$ & $0.6 \mathrm{~m}$ & Ktimatologio S.A. \\
$14 / 06 / 2009$ & Satellite image & - & $0.5 \mathrm{~m}$ & Google Earth (maxar technologies) \\
$20 / 06 / 2010$ & Aerial photo & $1: 30000$ & $1.5 \mathrm{~m}$ & HMGS \\
2011 & Orthophoto & $1: 15000$ & $0.6 \mathrm{~m}$ & Ktimatologio S.A. \\
$06 / 11 / 2012$ & Satellite image & - & $0.2 \mathrm{~m}$ & Google Earth (maxar technologies) \\
$29 / 04 / 2013$ & Satellite image & - & $0.5 \mathrm{~m}$ & Google Earth \\
$27 / 06 / 2016$ & Satellite image & - & $0.2 \mathrm{~m}$ & Google Earth (CNES / Airbus) \\
$28 / 06 / 2017$ & Satellite image & - & $0.3 \mathrm{~m}$ & Google Earth \\
$24 / 03 / 2019$ & Satellite image & - & $0.2 \mathrm{~m}$ & Google Earth (CNES / Airbus) \\
\hline
\end{tabular}

\subsection{Terrain Visualisation}

The contemporary landscape was created by draping the 1968 geo-rectified aerial photography onto the DEM with the use of 1968 topographic diagrams from the Hellenic Military Geographical Service - HMGS with 1:5000 scale. The 1968 topographic diagrams and the 1968 aerial photograph were used since it is the only combined data of the area before the first constrictions in the coastal zone (Fig. 3). After this, the correlation of sea level changes, beach erosion rates, sedimentological rates and the geomorphological characteristics were considered for the possible reconstruction of the area from $-10 \mathrm{~m}$ to +10 m elevations. 


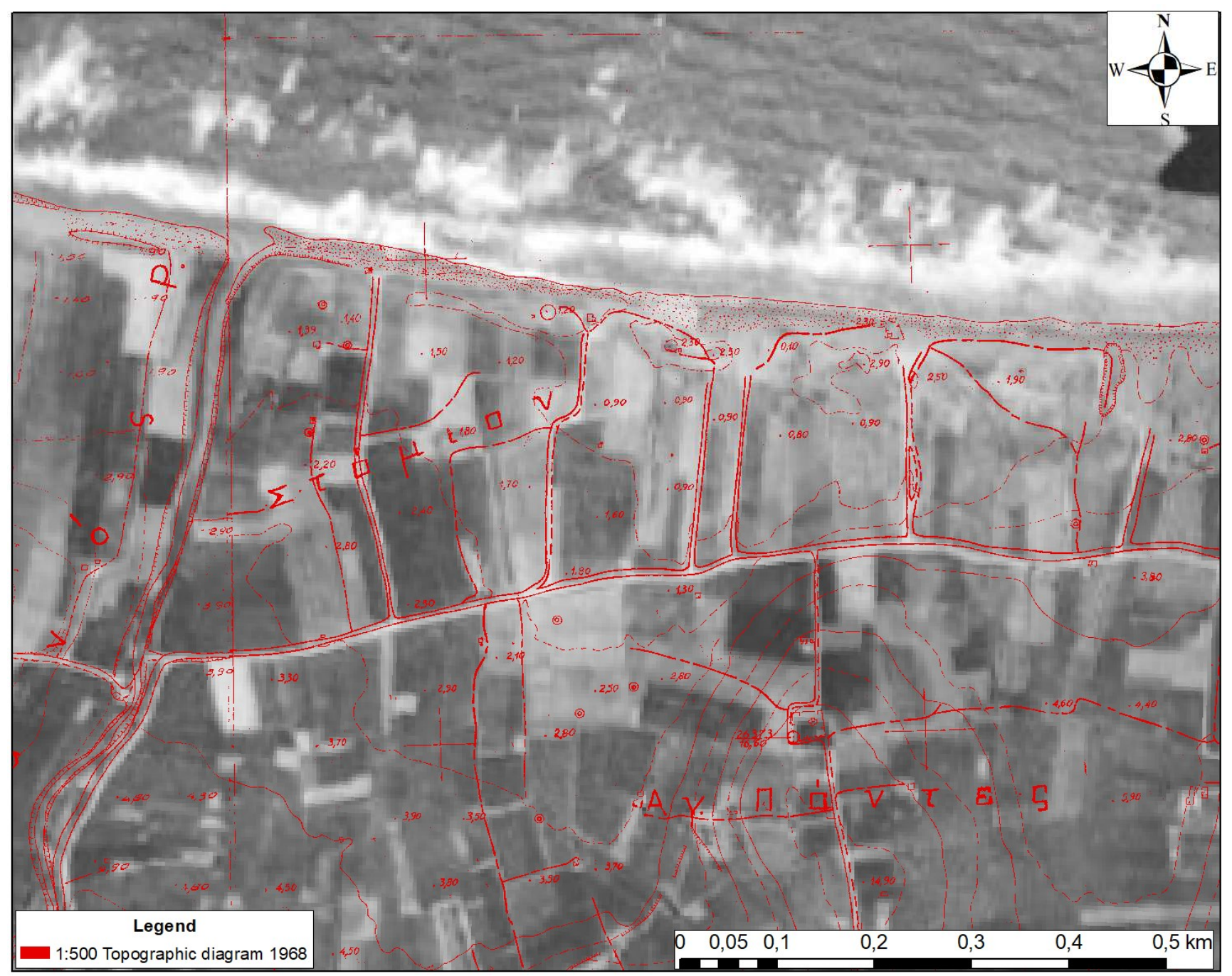

Figure 3. The 1968 aerial photograph and the elevations of the beach area based on the 1968 HMGS 1:5000 topographic diagram.

\section{RESULTS}

\subsection{Textural Characteristics}

The subaerial part of Ammoudara Beach consists generally of sand (S) and slightly gravely sand $((\mathrm{g}) \mathrm{S})$. The inner nearshore zone (between the shoreline and the reef) is generally characterized as slightly gravely sand $[(\mathrm{g}) \mathrm{S}]$, while seaward of the reef and in the nearshore zone of the western sector the seabed is predominantly covered by sands (S). At the vicinity of the mouth of the rivers Almiros, Gazanos, and Xiropotamos and toward the eastern end of Ammoudara Beach (close to the channelized Giofiros River), the sediments become coarser, varying from gravely sand (gS) to sandy gravel (sG). Relatively coarser material (i.e., sandy gravel (sG) and gravel $(\mathrm{G})$ ] is also observed along the landward side of the reef. In the western sector of Ammoudara Beach, the sediments become progressively finer from $\mathrm{W}$ to $\mathrm{E}$. The same trend exists in the central and eastern parts of the beach, with the exceptions of the small areas with coarser of the sediments (Fig. 4) 


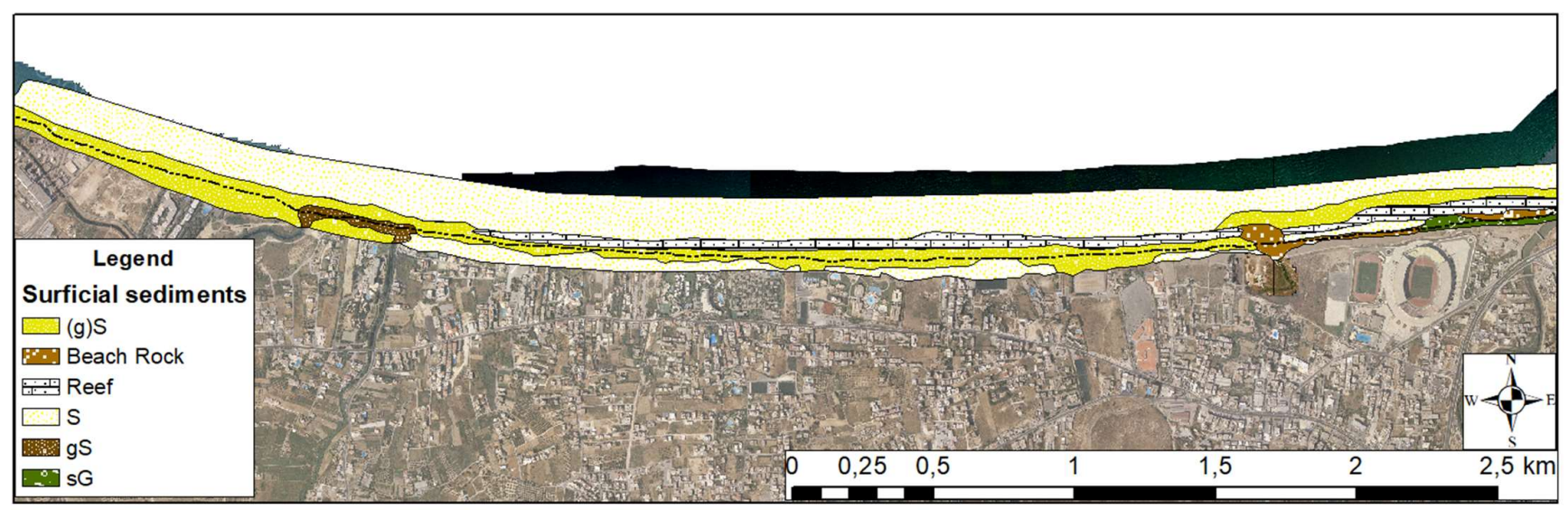

Figure 4. Textural characteristics (sand (S), slightly gravely sand ((g)S), gravely sand (gS), sandy gravel (sG), gravel (G) and locations of the shoreline beach rock and reef of the Ammoudara beach.

\subsection{Coastal evolution}

For the study of the stability of the coastline from 1945 until today, aerial photographs and satellite images were used. As it results from the examination of the aerial photographs for the years 1945, 1968 and 1998, there is a clear retreat of the coast due to its constant and permanent erosion by the waves. The retreat of the coastline is estimated to be $45 \mathrm{~m}$ on average. In the diagrams of all checkpoints, a displacement rate of $\pm 1.5 \mathrm{~m}$ has been calculated, which is due to the errors of georeferencing and digitization of the coastline of aerial photographs and satellite images. Small shoreline displacements $(< \pm 5$ $\mathrm{m}$ ) are considered within the limits of the expected transient changes in the terrain of the coastal zone due to ephemerous changes in hydrodynamic conditions and displacements due to transitions of the beach from cross section to storm cross section and, therefore, are not rated as significant. The results of the comparisons are presented in Figure 5 and Table 2.

Table 2: Changes in the position of the broader beach coastline in meters, on selected transects (for location see figure 5), during the period 1945-2020.

\begin{tabular}{ccccccc}
\hline Transects & $\mathbf{1 9 4 5 - 1 9 9 8}$ & $\mathbf{1 9 9 8 - 2 0 0 2}$ & $\mathbf{2 0 0 2 - 2 0 0 9}$ & $\mathbf{2 0 0 9 - 2 0 1 5}$ & $\mathbf{2 0 1 5 - 2 0 2 0}$ & $\mathbf{1 9 4 5 - 2 0 2 0}$ \\
\hline 20 & 0,0 & $-1,9$ & 3,4 & $-3,3$ & -4 & $\mathbf{- 3 . 4}$ \\
\hline 37 & $-17,8$ & $-11,0$ & 3,6 & 14,7 & $-12,4$ & $\mathbf{- 2 3 . 1}$ \\
\hline 50 & $-33,0$ & $-15,8$ & 15,2 & $-7,3$ & $-0,6$ & $\mathbf{- 4 1 . 4}$ \\
\hline 75 & $-40,9$ & $-8,7$ & 0,6 & $-0,3$ & $-4,7$ & $\mathbf{- 5 3 . 9}$ \\
\hline 90 & $-49,2$ & $-10,2$ & 3,3 & $-2,9$ & 3,3 & $\mathbf{- 5 5 . 6}$ \\
\hline 110 & $-53,7$ & $-7,2$ & 2,6 & $-3,5$ & 11,2 & $\mathbf{- 5 0 . 5}$ \\
\hline 125 & $-42,4$ & $-7,4$ & $-2,5$ & $-3,9$ & 9,8 & $\mathbf{- 3 1 . 4 5}$ \\
\hline
\end{tabular}




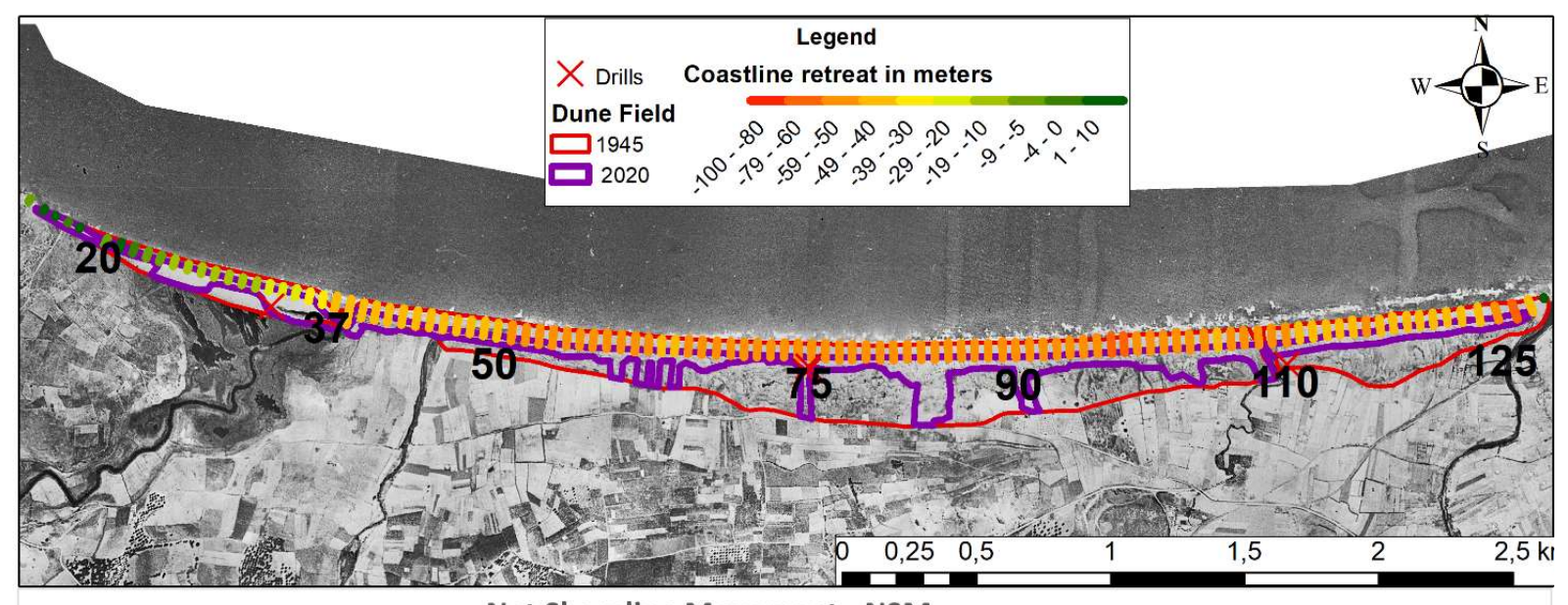

Net Shoreline Movement - NSM

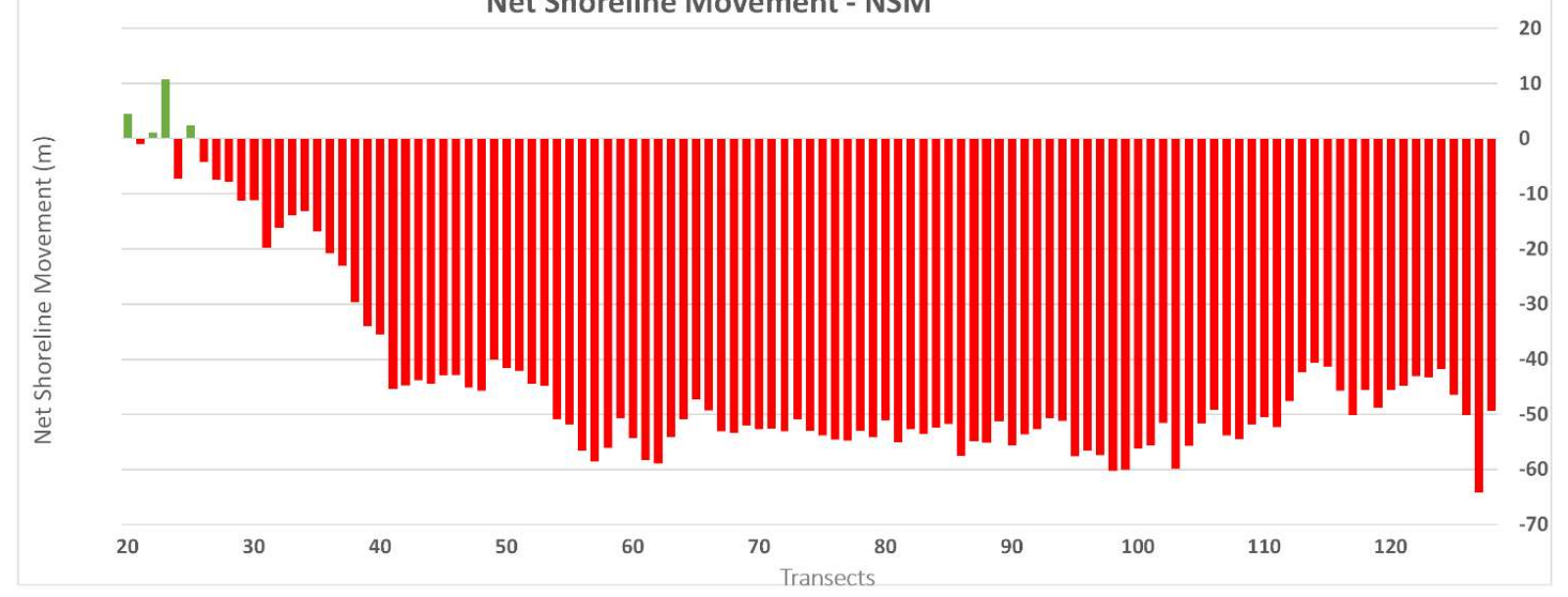

Figure 5. Coastal retreat in meters during the period 1945-2020. Location of the research drills and the selected transects of table 2. Expansion of the dune filed for the years 1945 and 2020 (above image). Net shoreline movements in meters per transect based on the DSAS assessments.

From the aerial photograph of 1945 (Fig. 5), it is seen that the dune field in 1945 was more extensive, with the wider coastal area having more accommodation space and availability of sediments. This indicates that during past periods the area had also an extensive wide land coastal zone and an abundance of fine-grained sediment. The aerial photograph of 1945 shows the boundary of the stabilized field of dunes (by sparse vegetation). Furthermore, the boundary of the fully developed field of dunes with denser vegetation is clearly visible. The analysis of the aerial photograph of 1945 shows that, at that time, the area of the transect 37 and Drill G3 was not affected by the waves. Instead, the affected area was located at the marsh of Almiros karstic spring delta, which is in line with the reports of early residents of the area.

\subsection{Stratigraphy}

To determine the stratigraphy of the area four research drills were made. The geographical characteristics of those are presented in table 3 while their locations in figure 5 . 
Table 3. topographical characteristics of the research drills.

\begin{tabular}{cccccc}
\hline No & Lat & Lon & Altitude & Distance from the coastline & depth \\
\hline G1 & $35^{\circ} 20^{\prime} 15.62^{\prime \prime} \mathrm{N}$ & $25^{\circ} 6^{\prime} 7.79 " \mathrm{E}$ & $2.45 \mathrm{~m}$ & $67.5 \mathrm{~m}$ & $10 \mathrm{~m}$ \\
\hline $\mathrm{G} 2$ & $35^{\circ} 20^{\prime} 14.73^{\prime \prime} \mathrm{N}$ & $25^{\circ} 4^{\prime} 53.74^{\prime \prime} \mathrm{E}$ & $2.33 \mathrm{~m}$ & $55 \mathrm{~m}$ & $10 \mathrm{~m}$ \\
\hline $\mathrm{G} 2^{\prime}$ & $35^{\circ} 20^{\prime} 14.40^{\prime \prime} \mathrm{N}$ & $25^{\circ} 04^{\prime} 53.57 " \mathrm{E}$ & $2.37 \mathrm{~m}$ & $51 \mathrm{~m}$ & $8 \mathrm{~m}$ \\
\hline $\mathrm{G} 3$ & $35^{\circ} 20^{\prime} 22.75^{\prime \prime} \mathrm{N}$ & $25^{\circ} 3^{\prime} 33.88^{\prime \prime} \mathrm{E}$ & $2,62 \mathrm{~m}$ & $76.6 \mathrm{~m}$ & $10 \mathrm{~m}$ \\
\hline
\end{tabular}

The stratigraphy of the first drill (G1) indicates that the soil layer extends from the surface down to $3 \mathrm{~m}$ depth. It consists of red sand soils and modern anthropogenic materials (e.g., building material, plastics). The next layer (3-6 m) is about $3 \mathrm{~m}$ thick and consists of sand with a small presence of clay. In the next $4 \mathrm{~m}(6-10 \mathrm{~m})$, there are sandy and gravelly sandy deposits, typical of coastal land dunes. At a depth of $7.5 \mathrm{~m}$, a layer of sandy gravel appears. From 8 to $10 \mathrm{~m}$ the material is sandy gravel. At a depth of $3.5 \mathrm{~m}$, 5.8-6 $\mathrm{m}$ and 8-8.3 $\mathrm{m}$, blind samples with codes G1CAD1, G1CAD2 and G1CAD3 were collected in a plastic tube for optical luminosity analysis.

In the second drill (G2), the soil horizon was found at the $0-2 \mathrm{~m}$ depth of the drilling, which consists of red-sand sands and anthropogenic materials. Then, the whole column shows $(2-10 \mathrm{~m})$ sandy and gravelly sandy deposits, typical of coastal land dunes. At a depth of $3.8 \mathrm{~m}$ and for $20 \mathrm{~cm}(3.8-4 \mathrm{~m})$, a layer of slightly coarse-grained material was found in the presence porous igneous volcanic rock that was identified as Pumice. Five blind samples were taken at depths of 4.1-4.4 m, 4.9-5.2 m, 6.2-6.4 m, 7.2-7.4 $\mathrm{m}$ and 9.5-10 $\mathrm{m}$, with sample codes G2CBD1, G2CBD2, G2CBD3, G2CBD4 and G2CBD5. In the same area in 2016, initial research drill (G2') was made for the collection of soil samples. The drilling data are in line with the latest data. The soil horizon was found at the depth of 0 $1.8 \mathrm{~m}$ of the drilling, which consists of red sands and carried anthropogenic materials. In the next about $20 \mathrm{~cm}(1.8-2.0 \mathrm{~m})$, the material is sand with a small presence of clay. In the next $1.5 \mathrm{~m}(2.0-3.5 \mathrm{~m})$, there are sandy and gravelly sandy deposits, typical of coastal inland dunes. At $3.5 \mathrm{~m}$ depth and for $20 \mathrm{~cm}(3.5-3.7 \mathrm{~m})$, a layer with slightly coarse material and the presence of pumice was found. From $3.7 \mathrm{~m}$ depth to $4.5 \mathrm{~m}$, the material is gravelly sand, while at $4.5 \mathrm{~m}$ depth is the aquifer, where a small horizon with clay sand at the depth of 4.5-4.7 $\mathrm{m}$ appears. From this depth until the end of the drilling (4.7-8 $\mathrm{m}$ ), the material is slightly gravelly sand. At a depth of $6.5 \mathrm{~m}$ ( $4.2 \mathrm{~m}$ below sea level), a remnant of pottery was found, which after a conversation with the archaeologist who has the license to study the area, there is a possibility that it is of Minoan origin, as it has similarities with those found on the adjacent plot, and at the same altitude [118].

In the third drilling (G3) the stratigraphy was slightly different due to the large presence of organic materials. The soil horizon can be seen at the depth $0-0.4 \mathrm{~m}$ of the drilling, which consists of grey sand soils and anthropogenic materials. In the next $1.6 \mathrm{~m}$ approximately $(0.4-2.0 \mathrm{~m})$, the material is sandy with a small presence of roots. In the next $4.2 \mathrm{~m}$ (2.0-6.m), there are grey sandy and gravelly sandy deposits, similar of coastal land dunes in the vicinity of a river system. From $6 \mathrm{~m}$ to the end of the drilling at a depth of 10 $\mathrm{m}$, there are grey sands with the presence of cobbles. At depths of 3.3 m, 6-6.2 $\mathrm{m}$ and 9.8$10 \mathrm{~m}$, blind samples with codes G3CARD1, G3CARD2 and G3CARD3 were sampled in plastic tubes for optical luminosity analyses. G3CARD1 and G3CARD2 consisted of slightly gravelly sand, while G1CAD3 was grey sandy gravel. The stratigraphy of all drills is shown in Figure 6. 


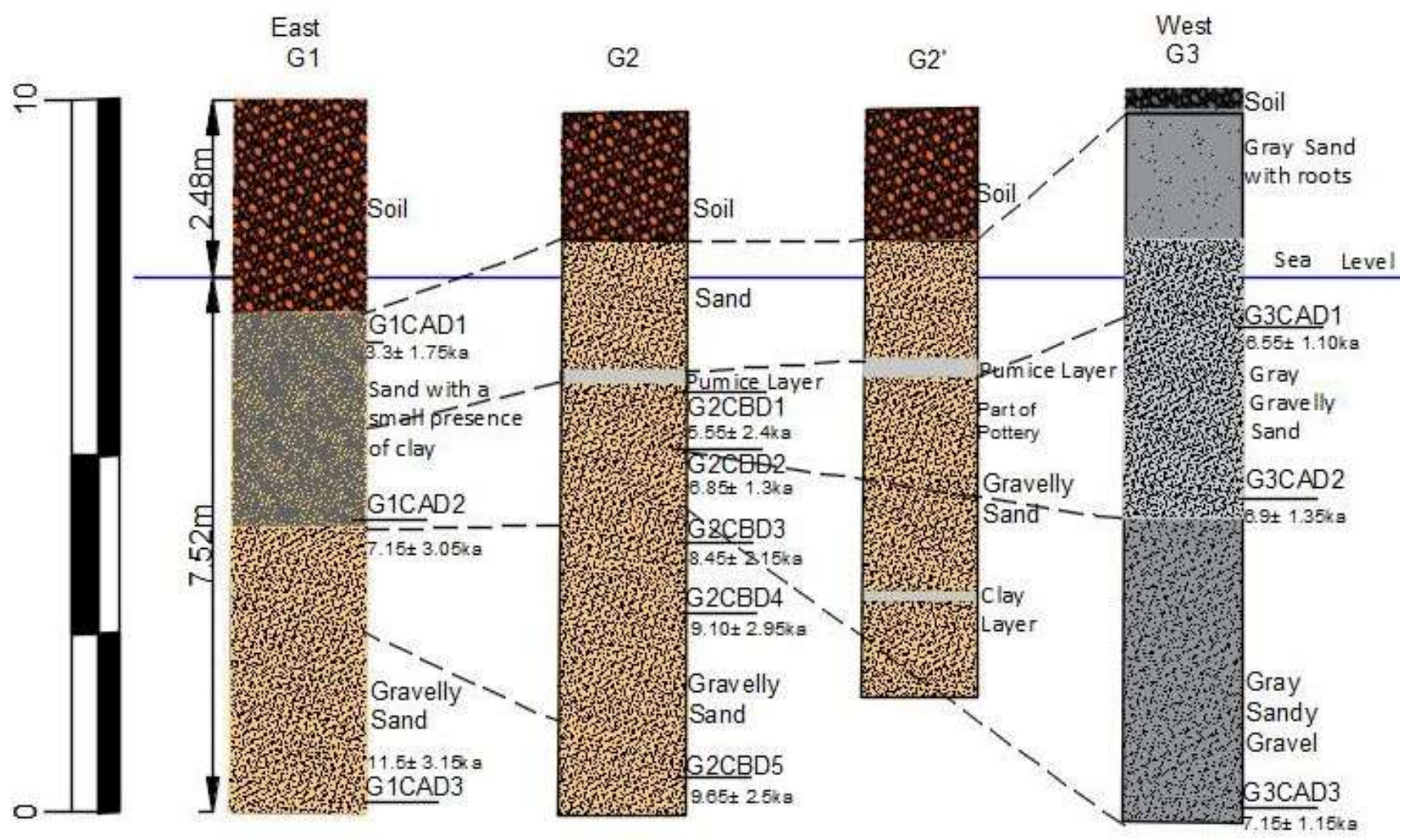

Figure 6. Stratigraphy of the drilling cores depth of samples and correlations between the various layers of sediments.

In all three locations, drillings showed that the deposits in the study area have the typical characteristics of subaerial coastal land and aeolian deposits, and no evidence emerged from anywhere that could lead to the opposite result of marine deposits. The stratigraphy of Ammoudara beach indicated that the dune system in the area is very old, since sand deposits were found in all cores and with ages reaching $11.5 \pm 3.15 \mathrm{ka}$. Sedimentological finds between $1.8 \mathrm{~m}$ and $8 \mathrm{~m}$ depth consist of sandy and gravely sandy deposits, which are typical coastal dune deposits. Few different layers were recognized, e.g. in G2 and G2' a layer between 3.5 and $3.7 \mathrm{~m}$. with slightly coarse material and the presence of pumice.

In all three locations, drillings showed that the deposits in the study area have the typical characteristics of coastal land and aeolian deposits, and no evidence emerged from anywhere that could lead to the opposite result of marine deposits. The stratigraphy of Ammoudara beach indicated that the dune system in the area is very old. Sedimentological finds between $1.8 \mathrm{~m}$. and $8 \mathrm{~m}$. depth consist of sandy and gravely sandy deposits, which are typical coastal dune deposits. Few different layers were recognized, e.g. in G2 and G2' a layer between 3.5 and $3.7 \mathrm{~m}$. with slightly coarse material and the presence of pumice.

\subsubsection{OLS results}

The equivalent doses (De) for the samples were estimated by interpolation of the natural dose in the dose response curve produced following the above protocols, the average values, with the corresponding standard deviation, are given in Table 4. 
Table 4. Equivalent doses estimated with OSL dose response curve lines.

\begin{tabular}{|c|c|c|c|c|c|c|c|c|c|c|c|c|c|}
\hline & & \multicolumn{4}{|c|}{ G1 } & \multicolumn{4}{|c|}{ G2 } & \multicolumn{4}{|c|}{ G3 } \\
\hline \multirow{2}{*}{\multicolumn{2}{|c|}{ Sample Code }} & & G1CA & S1CA & G1CA & G2CB & G2CB & G2CB & G2CB & $\overline{G 2 C B}$ & $\overline{\mathrm{G} 3 \mathrm{CAI}}$ & G3CAR & $\overline{\text { G3CAR }}$ \\
\hline & & & D2 & D3 & D4 & D1 & D2 & D3 & D4 & D5 & D1 & D2 & D3 \\
\hline $\begin{array}{c}\text { Equivalent } \\
\text { Dose (Gy) }\end{array}$ & $\begin{array}{c}\text { Mean } \pm 1 \text { sd } \\
\quad(N=18)\end{array}$ & $3.4 \pm 1.8$ & $\begin{array}{c}9.2 \pm \\
3.9\end{array}$ & $\begin{array}{c}9.9 \pm \\
2.7\end{array}$ & $\begin{array}{c}10.4 \pm \\
3.3\end{array}$ & $\begin{array}{c}3.7 \pm \\
1.6\end{array}$ & $\begin{array}{c}6.5 \pm \\
1.7\end{array}$ & $\begin{array}{c}5.6 \pm \\
1.1\end{array}$ & $\begin{array}{c}7.0 \pm \\
2.3\end{array}$ & $\begin{array}{c}6.9 \pm \\
1.8\end{array}$ & $\begin{array}{c}5.2 \pm \\
1.7\end{array}$ & $\begin{array}{c}8.0 \pm \\
3.9\end{array}$ & $\begin{array}{c}6.3 \pm \\
1.0\end{array}$ \\
\hline
\end{tabular}

Quality assurance parameters of the OSL measurements of the samples were also calculated. The recycle ratio was well below $10 \%$ and the recovery (signal at 0 Gy induced dose, compared to the natural dose) was less than $7.0 \%$ in all east borehole samples, $5.5 \%$ in Central drill and 3\% in western drilling. Finally, the dose recovery ratio (the estimated dose from a new dose response curve to a known given dose, i.e. 15 Gy) was also less than $10 \%$. All these values ensure the quality of the estimated equivalent doses for the samples. Recycling and dose recovery values are presented in Table 5.

Table 5. Quality assurance parameters of the OSL measurements.

\begin{tabular}{ccccc}
\hline \multirow{4}{*}{ G1 } & $\begin{array}{c}\text { SAMPLE } \\
\text { CODE }\end{array}$ & $\begin{array}{c}\text { RECYCLING } \\
\text { RATIO }\end{array}$ & $\begin{array}{c}\text { RECUPERATION } \\
\mathbf{( \% )}\end{array}$ & $\begin{array}{c}\text { DOSE RECOVERY } \\
\text { RATIO }\end{array}$ \\
\cline { 2 - 5 } & G1CAD1 & $1.06 \pm 0.09$ & $3.89 \pm 3.29$ & $0.93 \pm 0.17$ \\
\cline { 2 - 5 } & G1CAD2 & $1.04 \pm 0.10$ & $2.18 \pm 1.58$ & $0.96 \pm 0.13$ \\
\cline { 2 - 5 } & G1CAD3 & $1.02 \pm 0.25$ & $6.97 \pm 6.02$ & $0.91 \pm 0.21$ \\
\hline \hline \multirow{4}{*}{ G2 } & G1CAD4 & $0.98 \pm 0.13$ & $2.15 \pm 2.44$ & $0.98 \pm 0.19$ \\
\cline { 2 - 5 } & G2CBD1 & $1.08 \pm 0.09$ & $5.24 \pm 5.88$ & $0.92 \pm 0.15$ \\
\cline { 2 - 5 } & G2CBD2 & $1.11 \pm 0.11$ & $1.54 \pm 3.35$ & $0.94 \pm 0.24$ \\
\cline { 2 - 5 } & G2CBD3 & $1.08 \pm 0.10$ & $3.08 \pm 2.72$ & $0.97 \pm 0.17$ \\
\cline { 2 - 5 } & G2CBD4 & $1.01 \pm 0.14$ & $0.67 \pm 2.97$ & $0.91 \pm 0.13$ \\
\hline \hline \multirow{3}{*}{ G3 } & G2CBD5 & $1.01 \pm 0.14$ & $2.88 \pm 5.41$ & $0.95 \pm 0.19$ \\
\cline { 2 - 5 } & G3CARD1 & $1.06 \pm 0.05$ & $2.76 \pm 2.27$ & $0.95 \pm 0.14$ \\
\cline { 2 - 5 } & G3CARD2 & $1.02 \pm 0.10$ & $2.12 \pm 2.00$ & $0.93 \pm 0.11$ \\
\hline
\end{tabular}

\subsubsection{Radioactivity results}

Measurements of the activity of isotopes of ${ }^{238} \mathrm{U},{ }^{235} \mathrm{U},{ }^{232} \mathrm{Th}$ series and ${ }^{40} \mathrm{~K}$ and ${ }^{87} \mathrm{RB}$, in $\mathrm{Bq} / \mathrm{kg}$ and the calculated dose rate in $\mathrm{Gy} / \mathrm{ka}$ are presented in table 6. 
Table 6. Radioactivity measurements and the calculated dose rates.

\begin{tabular}{|c|c|c|c|c|c|c|c|c|}
\hline & & ISOTOPE & ${ }^{238} \mathrm{U}$ & ${ }^{235} \mathbf{U}$ & ${ }^{232} \mathrm{TH}$ & ${ }^{40} \mathrm{~K}$ & ${ }^{87} \mathbf{R B}$ & TOTAL \\
\hline \multirow{8}{*}{ G1 } & \multirow{2}{*}{$\begin{array}{c}\text { G1CAD } \\
1\end{array}$} & $\begin{array}{l}\text { Radioactivity } \\
(\mathrm{Bq} / \mathrm{kg})\end{array}$ & $17.5 \pm 1$ & $1.52 \pm 0.59$ & $11.9 \pm 0.9$ & $185.9 \pm 7.9$ & & \\
\hline & & Dose rate (Gy/ka) & $\begin{array}{c}0.337 \pm \\
0.022\end{array}$ & $0.012 \pm 0.005$ & $0.175 \pm 0.013$ & $0.494 \pm 0.021$ & 0.019 & $1.037 \pm 0.033$ \\
\hline & \multirow{2}{*}{$\begin{array}{c}\text { G1CAD } \\
2\end{array}$} & $\begin{array}{c}\text { Radioactivity } \\
(\mathrm{Bq} / \mathrm{kg})\end{array}$ & $18.4 \pm 1.1$ & $0.87 \pm 0.63$ & $15.7 \pm 1$ & $232.1 \pm 8.5$ & & \\
\hline & & Dose rate (Gy/ka) & $\begin{array}{c}0.341 \pm \\
0.022 \\
\end{array}$ & $0.007 \pm 0.005$ & $0.25 \pm 0.016$ & $0.668 \pm 0.025$ & 0.019 & $1.285 \pm 0.037$ \\
\hline & \multirow{2}{*}{$\begin{array}{c}\text { G1CAD } \\
3\end{array}$} & $\begin{array}{c}\text { Radioactivity } \\
(\mathrm{Bq} / \mathrm{kg})\end{array}$ & $14 \pm 0.8$ & $0.91 \pm 0.44$ & $9.3 \pm 0.7$ & $141.8 \pm 5.9$ & & \\
\hline & & Dose rate (Gy/ka) & $\begin{array}{c}0.274 \pm \\
0.018 \\
\end{array}$ & $0.008 \pm 0.004$ & $0.148 \pm 0.011$ & $0.41 \pm 0.017$ & 0.019 & $0.860 \pm 0.027$ \\
\hline & \multirow{2}{*}{$\begin{array}{c}\text { G1CAD } \\
4\end{array}$} & $\begin{array}{c}\text { Radioactivity } \\
(\mathrm{Bq} / \mathrm{kg})\end{array}$ & $14.6 \pm 0.9$ & $0.66 \pm 0.33$ & $9.4 \pm 0.7$ & $133.8 \pm 6.9$ & & \\
\hline & & Dose rate (Gy/ka) & $\begin{array}{c}0.283 \pm \\
0.019 \\
\end{array}$ & $0.006 \pm 0.003$ & $0.156 \pm 0.012$ & $0.402 \pm 0.021$ & 0.019 & $0.866 \pm 0.031$ \\
\hline \multirow{10}{*}{ G2 } & \multirow{2}{*}{ G2CBD1 } & $\begin{array}{c}\text { Radioactivity } \\
(\mathrm{Bq} / \mathrm{kg})\end{array}$ & $12.8 \pm 0.7$ & $0.97 \pm 0.36$ & $6.8 \pm 0.5$ & $104.9 \pm 4.5$ & & \\
\hline & & Dose rate (Gy/ka) & $\begin{array}{c}0.244 \pm \\
0.015\end{array}$ & $0.008 \pm 0.003$ & $0.106 \pm 0.008$ & $0.297 \pm 0.013$ & 0.019 & $0.675 \pm 0.021$ \\
\hline & \multirow{2}{*}{ G2CBD2 } & $\begin{array}{c}\text { Radioactivity } \\
(\mathrm{Bq} / \mathrm{kg})\end{array}$ & $13.8 \pm 0.8$ & $1.17 \pm 0.51$ & $7.8 \pm 0.6$ & $117.9 \pm 6.6$ & & \\
\hline & & Dose rate (Gy/ka) & $\begin{array}{c}0.272 \pm \\
0.018\end{array}$ & $0.01 \pm 0.004$ & $0.127 \pm 0.01$ & $0.344 \pm 0.019$ & 0.019 & $0.771 \pm 0.028$ \\
\hline & \multirow{2}{*}{ G2CBD3 } & $\begin{array}{c}\text { Radioactivity } \\
(\mathrm{Bq} / \mathrm{kg})\end{array}$ & $9.9 \pm 0.7$ & $0.37 \pm 0.29$ & $8.9 \pm 0.6$ & $168.1 \pm 11.2$ & & \\
\hline & & Dose rate (Gy/ka) & $\begin{array}{c}0.176 \pm \\
0.013\end{array}$ & $0.003 \pm 0.002$ & $0.14 \pm 0.01$ & $0.477 \pm 0.032$ & 0.019 & $0.815 \pm 0.036$ \\
\hline & \multirow{2}{*}{ G2CBD4 } & $\begin{array}{c}\text { Radioactivity } \\
(\mathrm{Bq} / \mathrm{kg})\end{array}$ & $11.3 \pm 0.7$ & $0.36 \pm 0.3$ & $8 \pm 0.6$ & $146.9 \pm 6.6$ & & \\
\hline & & Dose rate (Gy/ka) & $\begin{array}{c}0.212 \\
\pm 0.015 \\
\end{array}$ & $0.003 \pm 0.002$ & $0.125 \pm 0.01$ & $0.413 \pm 0.019$ & 0.019 & $0.772 \pm 0.026$ \\
\hline & \multirow{2}{*}{ G2CBD5 } & $\begin{array}{c}\text { Radioactivity } \\
(\mathrm{Bq} / \mathrm{kg})\end{array}$ & $11 \pm 0.7$ & $0.41 \pm 0.29$ & $8.1 \pm 0.6$ & $148.6 \pm 16.1$ & & \\
\hline & & Dose rate (Gy/ka) & $\begin{array}{c}0.189 \pm \\
0.014 \\
\end{array}$ & $0.003 \pm 0.002$ & $0.117 \pm 0.009$ & $0.389 \pm 0.042$ & 0.019 & $0.717 \pm 0.045$ \\
\hline \multirow{6}{*}{ G3 } & \multirow{2}{*}{$\begin{array}{c}\text { G3CAR } \\
\text { D1 }\end{array}$} & $\begin{array}{c}\text { Radioactivity } \\
(\mathrm{Bq} / \mathrm{kg})\end{array}$ & $16.6 \pm 0.9$ & $1.07 \pm 0.56$ & $8 \pm 0.6$ & $136.8 \pm 6.7$ & & \\
\hline & & Dose rate (Gy/ka) & $\begin{array}{c}0.243 \pm \\
0.016 \\
\end{array}$ & $0.008 \pm 0.004$ & $0.114 \pm 0.009$ & $0.355 \pm 0.017$ & 0.019 & $0.739 \pm 0.026$ \\
\hline & \multirow{2}{*}{$\begin{array}{c}\text { G3CAR } \\
\text { D2 }\end{array}$} & $\begin{array}{c}\text { Radioactivity } \\
(\mathrm{Bq} / \mathrm{kg})\end{array}$ & $16.7 \pm 0.9$ & $0.84 \pm 0.42$ & $11.3 \pm 0.8$ & $190.7 \pm 7.2$ & & \\
\hline & & Dose rate (Gy/ka) & $\begin{array}{c}0.301 \pm \\
0.019 \\
\end{array}$ & $0.007 \pm 0.004$ & $0.181 \pm 0.012$ & $0.55 \pm 0.021$ & 0.019 & $1.058 \pm 0.031$ \\
\hline & \multirow{2}{*}{$\begin{array}{c}\text { G3CAR } \\
\text { D3 }\end{array}$} & $\begin{array}{c}\text { Radioactivity } \\
(\mathrm{Bq} / \mathrm{kg})\end{array}$ & $13.2 \pm 0.8$ & $0.68 \pm 0.46$ & $9.3 \pm 0.7$ & $155.7 \pm 6.4$ & & \\
\hline & & Dose rate (Gy/ka) & $\begin{array}{c}0.255 \pm \\
0.017\end{array}$ & $0.006 \pm 0.004$ & $0.151 \pm 0.011$ & $0.457 \pm 0.019$ & 0.019 & $0.887 \pm 0.028$ \\
\hline
\end{tabular}


Dose rates were corrected for the moisture content of the raw samples. Using the equivalent doses that are given in Table 6 (averages \pm 1 sd) the calculated ages and the range (min-max) are given in Table 7.

Table 5. Equivalent doses, dose rates and calculated ages in y before present.

\begin{tabular}{|c|c|c|c|c|c|c|}
\hline & $\begin{array}{c}\text { SAMPLE } \\
\text { CODE }\end{array}$ & $\begin{array}{c}\text { EQUIVALENT } \\
\text { DOSE (GY) }\end{array}$ & $\begin{array}{c}\text { DOSE RATES } \\
\text { (GY/KA) }\end{array}$ & AGES (Y) & $\begin{array}{c}\text { MIN-MAX } \\
(\mathrm{Y}) \\
\end{array}$ & $\begin{array}{c}\text { MOISTU } \\
\text { RE (\%) }\end{array}$ \\
\hline \multirow{4}{*}{ G1 } & G1CAD1 & $3.4 \pm 1.8$ & $1.037 \pm 0.033$ & $3300 \pm 1750$ & $1500-7400$ & 21.280 \\
\hline & G1CAD2 & $9.2 \pm 3.9$ & $1.285 \pm 0.037$ & $7150 \pm 3050$ & $3600-17550$ & 13.120 \\
\hline & G1CAD3 & $9.9 \pm 2.7$ & $0.860 \pm 0.027$ & $\begin{array}{c}11500 \pm \\
3150\end{array}$ & $7800-21000$ & 12.523 \\
\hline & G1CAD4 & $10.4 \pm 3.3$ & $0.866 \pm 0.031$ & $\begin{array}{c}12050 \pm \\
3800\end{array}$ & $7900-25300$ & 8.893 \\
\hline \multirow{5}{*}{ G2 } & G2CBD1 & $3.7 \pm 1.6$ & $0.675 \pm 0.021$ & $5500 \pm 2400$ & $2400-12900$ & 14.591 \\
\hline & G2CBD2 & $5.6 \pm 1.1$ & $0.815 \pm 0.036$ & $6850 \pm 1300$ & $4450-9500$ & 14.519 \\
\hline & G2CBD3 & $6.5 \pm 1.7$ & $0.771 \pm 0.028$ & $8450 \pm 2150$ & $5300-13050$ & 11.732 \\
\hline & G2CBD4 & $7.0 \pm 2.3$ & $0.772 \pm 0.026$ & $9100 \pm 2950$ & $6150-16450$ & 15.477 \\
\hline & G2CBD5 & $6.9 \pm 1.8$ & $0.717 \pm 0.045$ & $9650 \pm 2500$ & $5250-13850$ & 22.991 \\
\hline \multirow{3}{*}{ G3 } & $\begin{array}{c}\text { G3CAR } \\
\text { D1 }\end{array}$ & $5.2 \pm 1.7$ & $0.739 \pm 0.026$ & $6550 \pm 1100$ & $4850-8800$ & 23.923 \\
\hline & $\begin{array}{c}\text { G3CAR } \\
\text { D2 } \\
\end{array}$ & $8.0 \pm 3.9$ & $1.058 \pm 0.031$ & $6900 \pm 1350$ & $3800-9400$ & 12.839 \\
\hline & $\begin{array}{c}\text { G3CAR } \\
\text { D3 }\end{array}$ & $6.3 \pm 1.0$ & $0.887 \pm 0.028$ & $7150 \pm 1150$ & $5600-9500$ & 11.221 \\
\hline
\end{tabular}

Distributions of the calculated ages, for the samples, are given in Figure 7, while individual ED values are given in Table 6. 


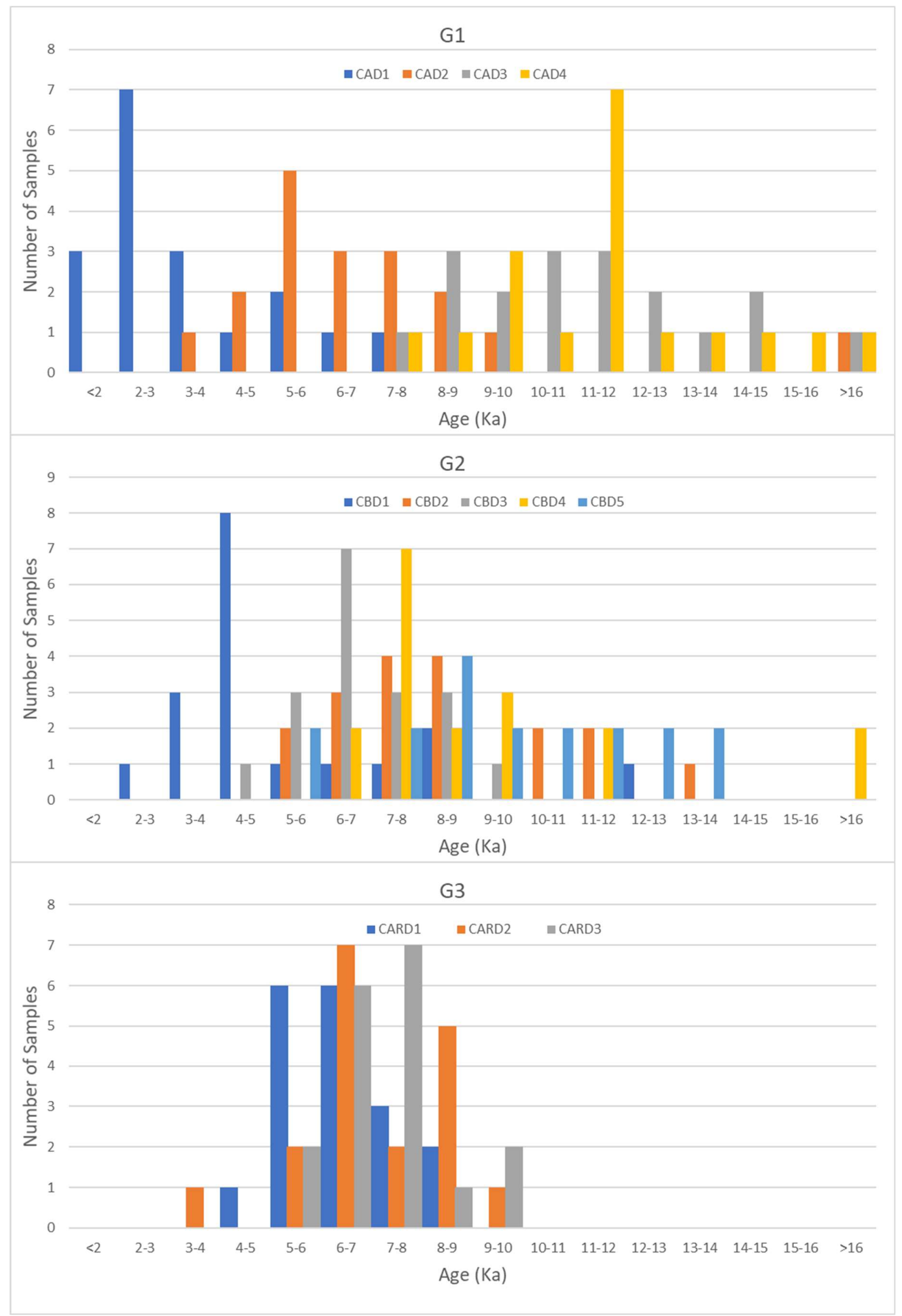

Figure 7. Distribution of the calculated ages (in ka) for the number of samples. 
Table 6. Individual OSL ages (y).

\begin{tabular}{|c|c|c|c|c|c|c|c|c|c|c|c|c|}
\hline \multirow{2}{*}{$\begin{array}{c}\text { OSL } \\
\operatorname{Age}(y) \\
N\end{array}$} & \multicolumn{4}{|c|}{ G1 } & \multicolumn{5}{|c|}{ G2 } & \multicolumn{3}{|c|}{ G3 } \\
\hline & CAD1 & CAD2 & CAD3 & CAD4 & CBD1 & CBD2 & CBD3 & CBD4 & CBD5 & CARD1 & CARD2 & CARD3 \\
\hline 1 & 1511 & 3604 & 7781 & 7892 & 2377 & 5313 & 4447 & 6170 & 5246 & 4854 & 3808 & 5586 \\
\hline 2 & 1551 & 4862 & 8010 & 8666 & 3505 & 5671 & 5070 & 6702 & 5632 & 5416 & 5251 & 5638 \\
\hline 3 & 1796 & 4886 & 8506 & 9271 & 3842 & 6728 & 5816 & 7009 & 7083 & 5457 & 5681 & 6080 \\
\hline 4 & 2072 & 5014 & 8775 & 9345 & 4000 & 6873 & 5939 & 7054 & 7547 & 5675 & 6153 & 6153 \\
\hline 5 & 2167 & 5671 & 9312 & 9980 & 4114 & 6878 & 6258 & 7064 & 8322 & 5757 & 6176 & 6205 \\
\hline 6 & 2192 & 5738 & 9913 & 10644 & 4340 & 7102 & 6355 & 7123 & 8659 & 5776 & 6309 & 6217 \\
\hline 7 & 2195 & 5830 & 10219 & 11085 & 4495 & 7107 & 6362 & 7618 & 8762 & 5982 & 6361 & 6333 \\
\hline 8 & 2211 & 5888 & 10344 & 11101 & 4527 & 7461 & 6433 & 7878 & 8960 & 6098 & 6406 & 6630 \\
\hline 9 & 2373 & 6316 & 10969 & 11250 & 4562 & 7901 & 6443 & 7948 & 9083 & 6237 & 6506 & 7023 \\
\hline 10 & 2709 & 6647 & 11319 & 11336 & 4637 & 8065 & 6446 & 8282 & 9265 & 6694 & 6855 & 7273 \\
\hline 11 & 3069 & 6943 & 11440 & 11367 & 4933 & 8493 & 6816 & 8969 & 10100 & 6710 & 7002 & 7456 \\
\hline 12 & 3397 & 7233 & 11463 & 11979 & 4988 & 8612 & 7071 & 9009 & 10264 & 6765 & 7123 & 7487 \\
\hline 13 & 3689 & 7260 & 12293 & 11998 & 5749 & 8831 & 7082 & 9113 & 11037 & 6891 & 8080 & 7775 \\
\hline 14 & 4144 & 7854 & 12718 & 12655 & 6670 & 10016 & 7286 & 9284 & 11380 & 7194 & 8247 & 7825 \\
\hline 15 & 5191 & 8376 & 13543 & 13949 & 7180 & 10232 & 8410 & 11092 & 12131 & 7789 & 8319 & 7965 \\
\hline 16 & 5202 & 8832 & 14363 & 14390 & 8048 & 11706 & 8478 & 11095 & 12743 & 7792 & 8392 & 8266 \\
\hline 17 & 6410 & 9786 & 14877 & 15033 & 8203 & 11899 & 8878 & 16066 & 13644 & 8281 & 8448 & 9137 \\
\hline 18 & 7425 & 17558 & 20977 & 25282 & 12904 & 13062 & 9492 & 16427 & 13835 & 8799 & 9401 & 9516 \\
\hline
\end{tabular}

Considering the values of the total of the disks used for the OSL measurements, the averages and the associated 1sd are given to the 3rd, 7th, 11th and 15th line of Table 6. The methodology used to calculate the mean age and relative standard deviation considers the total number of tablets (i.e., pellet samples, placed in suitable tablets for passage through the machine) which is $\mathrm{N}=18$, and then applying appropriate exclusion criteria, excludes some non-contributing tablets, namely $\mathrm{N}=6$, and from the rest $\mathrm{N}=12$, gives values that are rounded to multiples of 50 years. Considering the values of the total number of tablets used for the OSL measurements, the averages and the relative sd are obtained. 
Table 7. Calculated age averages with the associated standard deviation considering the total number of disks $(\mathrm{N}=18)$ and excluding some of the values $(\mathrm{N}=12)$. Values are rounded to multiples of $50 \mathrm{y}$.

\begin{tabular}{|c|c|c|c|c|}
\hline & SAMPLE CODE & & 18 & 12 \\
\hline \multirow{8}{*}{ G1 } & \multirow{2}{*}{ G1CAD1 } & Average \pm 1sd (y) & $3300 \pm 1750$ & $2950 \pm 1000$ \\
\hline & & Relative error ( $\%)$ & 53.0 & 33.9 \\
\hline & \multirow{2}{*}{ G1CAD2 } & Average \pm 1sd (y) & $7150 \pm 3050$ & $6550 \pm 1000$ \\
\hline & & Relative error (\%) & 42.7 & 15.3 \\
\hline & \multirow{2}{*}{ G1CAD3 } & Average \pm 1sd (y) & $11500 \pm 3150$ & $11050 \pm 1400$ \\
\hline & & Relative error $(\%)$ & 27.4 & 12.7 \\
\hline & \multirow{2}{*}{ G1CAD4 } & Average \pm 1sd (y) & $12050 \pm 3800$ & $11400 \pm 1200$ \\
\hline & & Relative error $(\%)$ & 31.5 & 10.5 \\
\hline \multirow{10}{*}{ G2 } & \multirow{2}{*}{ G2CBD1 } & Average \pm 1sd (y) & $5500 \pm 2400$ & $5000 \pm 1000$ \\
\hline & & Relative error $(\%)$ & 43.6 & 20.0 \\
\hline & \multirow{2}{*}{ G2CBD2 } & Average \pm 1sd (y) & $6850 \pm 1300$ & $6750 \pm 650$ \\
\hline & & Relative error (\%) & 19.0 & 9.6 \\
\hline & \multirow[t]{2}{*}{ G2CBD3 } & Average \pm 1sd (y) & $8450 \pm 2150$ & $8150 \pm 1150$ \\
\hline & & Relative error (\%) & 25.4 & 14.1 \\
\hline & \multirow{2}{*}{ G2CBD4 } & Average \pm 1sd (y) & $9100 \pm 2950$ & $8350 \pm 1200$ \\
\hline & & Relative error $(\%)$ & 32.4 & 14.4 \\
\hline & \multirow[t]{2}{*}{ G2CBD5 } & Average \pm 1sd (y) & $9650 \pm 2500$ & $9650 \pm 1350$ \\
\hline & & Relative error (\%) & 25.9 & 14.0 \\
\hline \multirow{6}{*}{ G3 } & \multirow[t]{2}{*}{ G3CARD1 } & Average \pm 1sd (y) & $6550 \pm 1100$ & $6450 \pm 650$ \\
\hline & & Relative error $(\%)$ & 16.8 & 10.1 \\
\hline & \multirow{2}{*}{ G3CARD2 } & Average \pm 1sd (y) & $6900 \pm 1350$ & $6950 \pm 800$ \\
\hline & & Relative error (\%) & 19.6 & 11.5 \\
\hline & \multirow{2}{*}{ G3CARD3 } & Average \pm 1sd (y) & $7150 \pm 1150$ & $7050 \pm 700$ \\
\hline & & Relative error (\%) & 16.1 & 9.9 \\
\hline
\end{tabular}

Excluding the mean calculations, the top three (G1CAD1, G2CBD1, G3CARD1) and bottom three ages (G1CAD3 G1CAD4 G2CBD5), as well as the calculated averages are still in the 1sd range and samples G1CAD1, G1CAD2, G1CAD3 and G1CAD4 present relative errors of $33.9,15.3,12.3$ and 10.5 respectively. $14.0 \%$, which are lower than the 53.0, 42.7, 27.7 and 31.5 of the initial prices (Table 9). For samples G2CBD1, G2CBD2, G2CBD3, G2CBD4 and G2CBD5, the calculated averages are still in the 1sd range and show relative errors of 20.0, 14.1, 9.6, 14.4 and $14.0 \%$, lower than 43.6, 25.4, 19.0, 32.4 and $25.9 \%$ of the initial values (Table 7). While for samples G3CARD1, G3CARD2 and G3CARD3, the calculated averages are still in the 1sd range and show relative errors of $10.1,11.5$ and $9.9 \%, 20.0,14.1,9.6,14.4$ and $14.0 \%$, lower than the $16.8,19.6$ and $16.1 \%$ of the initial prices (Table 9). Finally, typical OSL curves of the samples are given in Figure 9. 

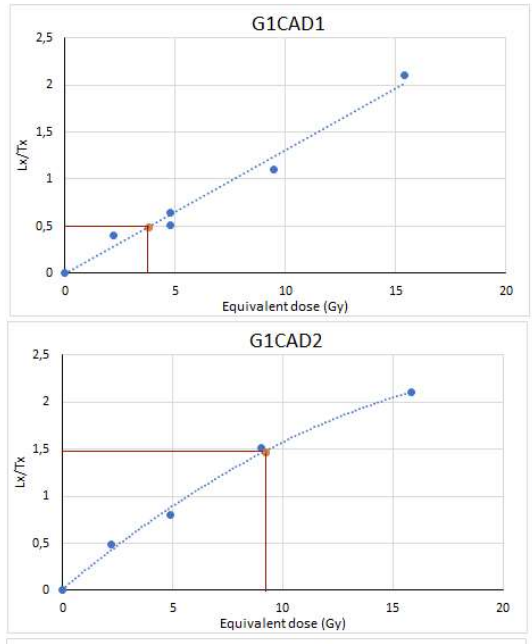

G1CAD3
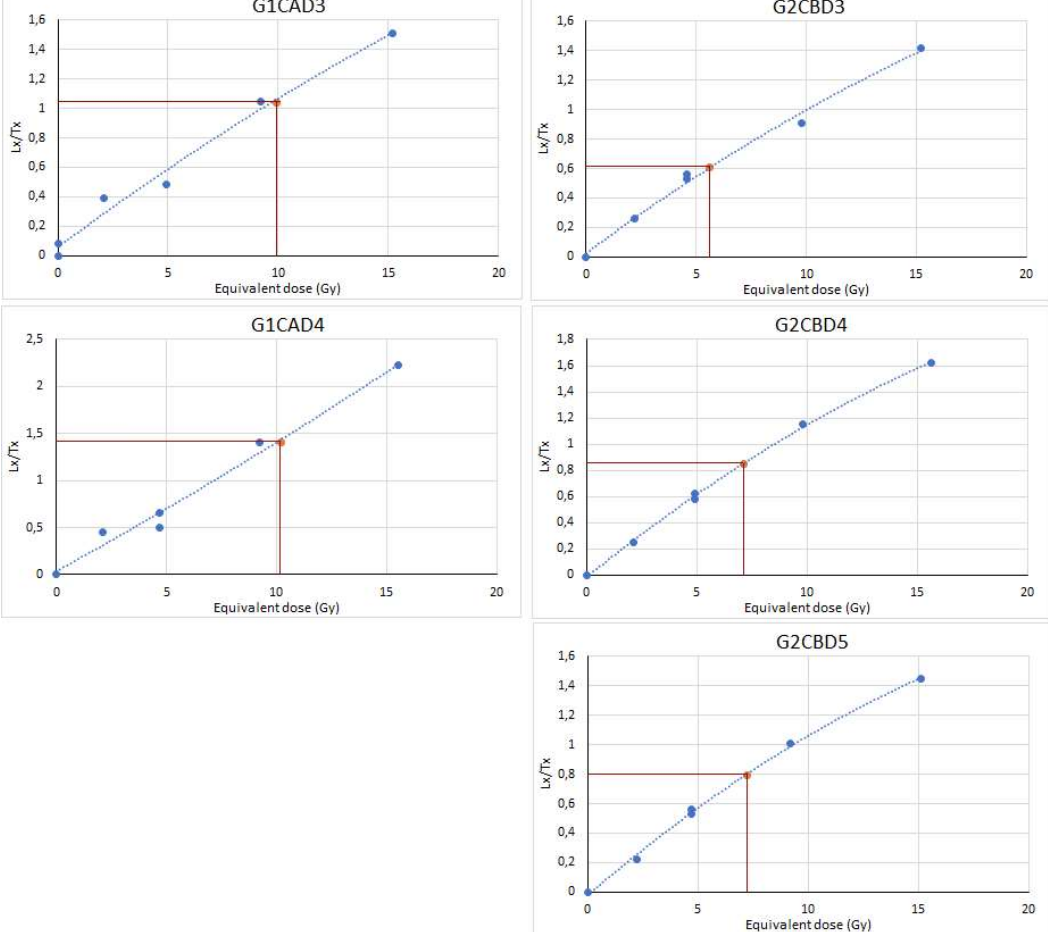
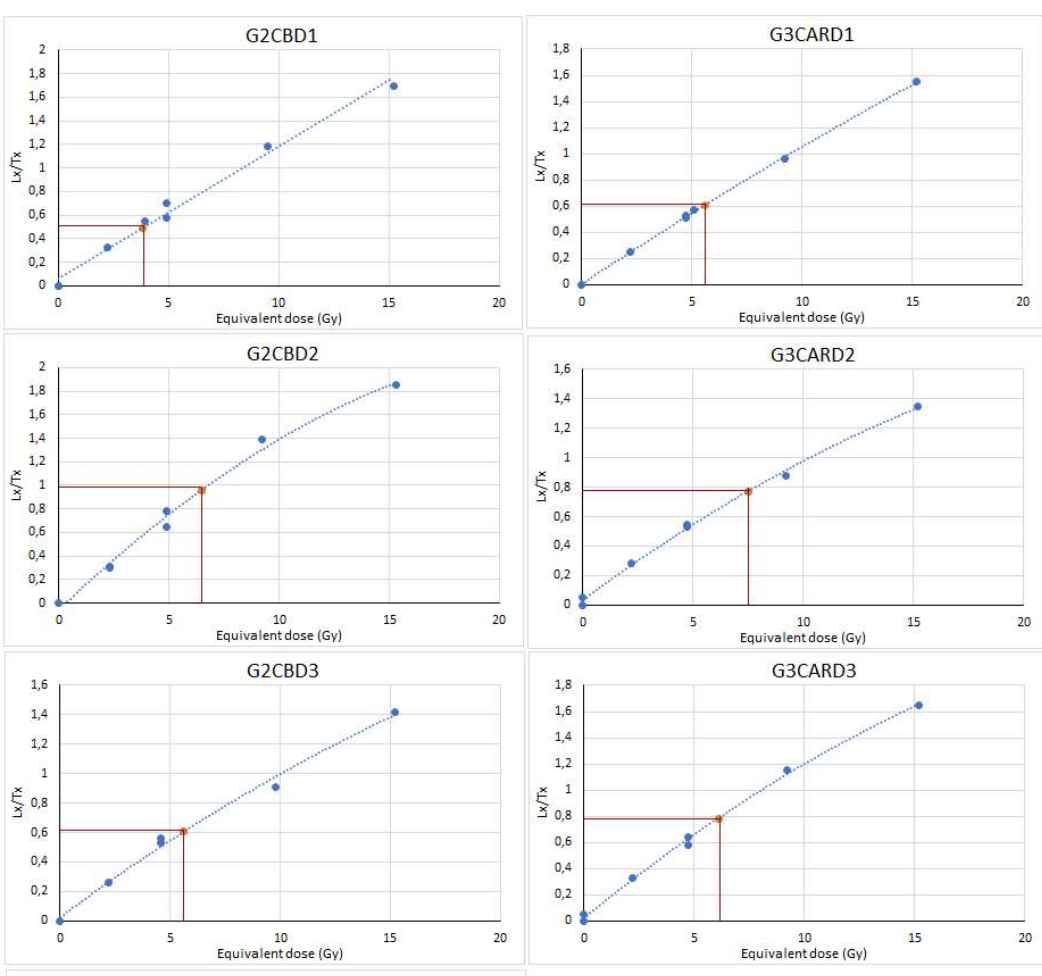

Figure 9. Typical OSL dose response curve curvesThe y-axis shows the ratios obtained for each of these artificial doses (Lx/Tx) and for the natural sample ( $\mathrm{Ln} / \mathrm{Tn})$.

\section{Discussion}

The older age cluster of sediment ages falls between 10.5 and $12.0 \mathrm{ka}$ and in-depth 7.5-8.5 $\mathrm{m}$ in the western area of the beach. It encompasses the period of the initial growth of the dune field, while it is affected by the Almiros karstic spring delta. In the Eastern part, samples consistently produced slightly younger ages and mainly around $6 \mathrm{ka}$. In the central part a clearer stratigraphy is present. Ages start from around $5 \mathrm{ka}$ ago at $4 \mathrm{~m}$ depth and $6.5 \mathrm{ka}$ ago in the depth of $6.5 \mathrm{~m}$, where the Bronze age archaeological remains were found. Note that the Minoan civilization was a Bronze Age Aegean civilization on the island of Crete and other Aegean Islands was flourishing from c. 3000 BC to c. 1450 BC. In the depth of $7.2 \mathrm{~m}$ the age of the sediments appears to be around $9 \mathrm{ka}$, while in the depth of $9.5 \mathrm{~m}$, the age in around $10 \mathrm{ka}$. Based on those findings the sedimentological rate for the formation of the dune fields in each area is $0.84 \mathrm{~m} / 1000 \mathrm{y}$ in the east part, $1.04 \mathrm{~m} / 1000$ 
$\mathrm{y}$ in the central part and $1.4 \mathrm{~m} / 1000 \mathrm{y}$ in the western part, which indicated a faster sedimentological process that may be the result from the river sediments availability (Fig. 8 ). One of the goals of this work was to determine the rate and extent of beach evolution and how it might affect the discoverability of archaeological sites. If the sediment transfer and coastal erosion were rapid enough, they might not be easily discernible using OSL dating as the progression of ages would fall within the ages' standard errors, especially at specific location. However, it appears that any dune evolution in the area, represented by the wider range of ages for the samples from $4 \mathrm{~m}$ depth, as well as the younger age cluster from shallower depth did not provide any indications of age inconsistencies. At all drill sites, OSL ages indicate that there is a correlation between depth and ages. Especially the $4.1 \mathrm{~m}$ depth sample in Drill G2 is consistent with the depth of the Minoan site excavation, and the pumice layer that indicate a volcanic event [119]. 


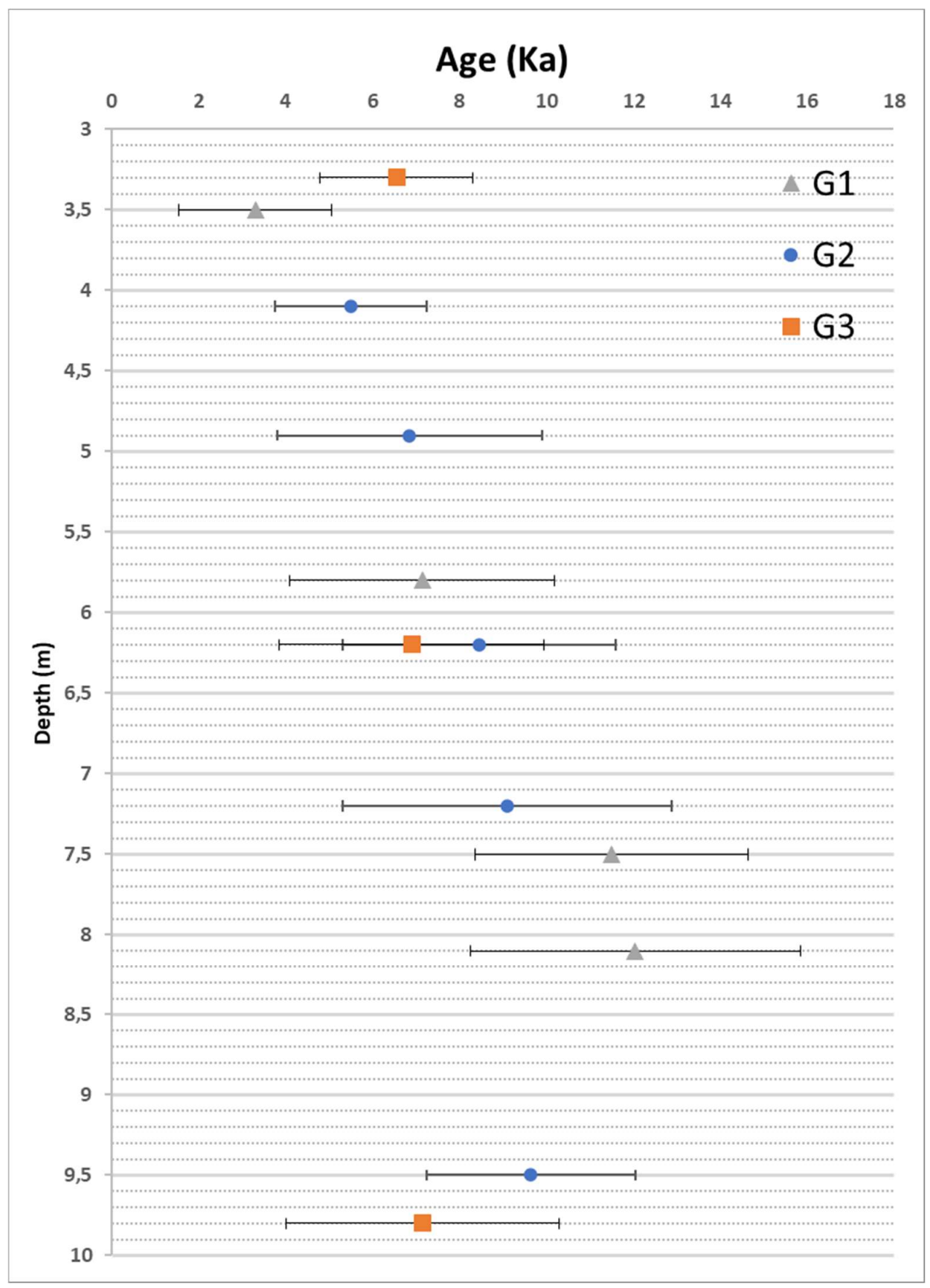

Figure 10. OSL ages with $1 \sigma$ errors vs. depth for samples.

Based on the above findings, a potential DEM of the area was generated by inputting the tectonic movements and the sea level rise rates for the last 6000 years and combining these with archaeological data from the same area. The proposed DEM can be used as the future basis for a more detailed reconstruction in order to better understand the landscape archaeology of the area [120]. However, there are several methodological limitations that need to be overcome. The topographic diagram of 1960, although of relatively large scale (1:5000) requires careful interpretation of boundaries and features. The map is also a record of property, and agricultural land. This raises the important question of whether the mapping should be constrained by the actual features shown on a particular map or whether other sources of documentary evidence and physical factors (soil type, topography) should be used to interpret the past and create a representative rather than 
an actual landscape. Based on the topographic and bathymetric field measurements, the current elevations and bathymetry were created. The Ammoudara beach zone of $6 \mathrm{ka} B P$ appears wider by 80 meters in the reconstructed DEM and the dune field is more developed (Fig. 11). The area behind the dune system had a higher altitude, while the area where the Minoan building was found was at a distance from the dune system. During the last decades, there is an noticeable loss of beach sediments, as indicated by the degradation of the dunes and the overall decline of the coastline.
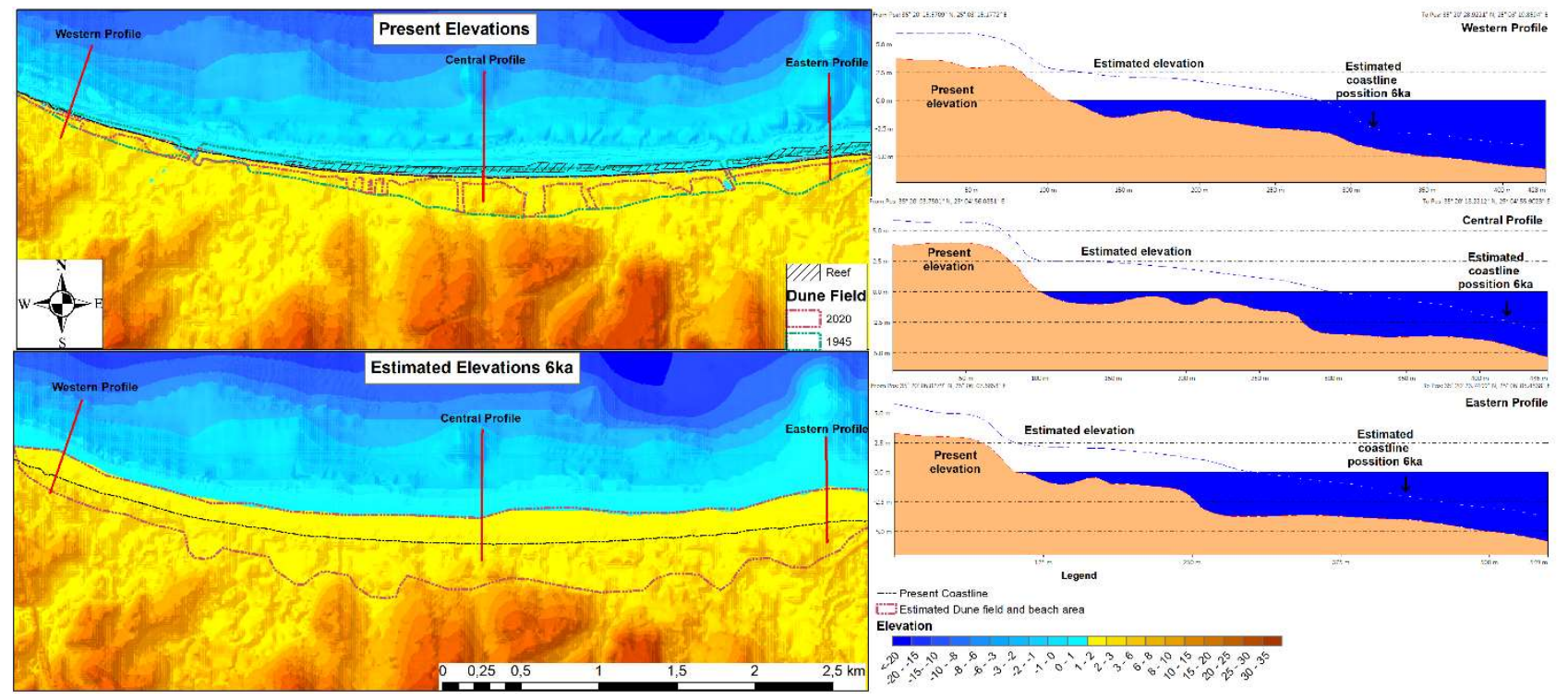

Figure 11. Current elevations, current position of the reef and the coastline and extent of the dune fields for 1945 and 2000 (upper left image). Estimated elevations and estimation of the extent of the dune field 6ka (bottom left image).

Representative profiles of current and estimated elevation, and estimated shoreline position 6ka (right image).

The latter is also associated with the increased distance between the reef and the coastline in the central and eastern parts of the coastal zone and the presence of coastal rocks in its western part. The loss of large amounts of sediment is intricately linked to the circulation of water on land and the relative transport of sediment, as well as human intervention and the relative rise in sea level. The former includes reductions in land sediment flows because of infrastructure development, coastal urbanization, and arbitrary disturbance of the dunes, while the latter may be related to climate change and sea level rise $>3 \mathrm{~mm} / \mathrm{a}$, since 1980 [10], as well as a possible natural reduction of the coastal zone through the condensation of river deposits.

This gradual loss of marine sediments in recent decades has caused changes in the topography of the sea (depth, reef development), to which the hydrodynamic conditions have been dynamically adapted, continuing the removal of sea sediments. This loss of sediment is generally associated with sediment transport to the east, while the loss of sediment in the offshore zone is favoured by reef openings in front of river estuaries. These findings agree with the conceptual model of Alexandrakis et al. [113]. In this conceptual model, it is reported that as sea level rise, newer dunes eroded, and stable wind reserves came to the surface. At the same time, coastal formation developed on the coastline. Then, as the sea level reached its current stage, the coastal erosion removed the sediment from the beach and finally the beachrock separated from the beach, sank, and formed the current reef. In this model, it is stated that there were multiple lines of dunes; the older being quite stable and hosting an alluvial area behind them. As the sea level rise, younger dunes were eroded and stable aeolian deposits were brought to the surface. Concurrently, a beachrock formation was developing in the coastline. As the sea level began to rise, coastal erosion removed sediments from the beach and, eventually, the 
beachrock was separated from the beach, submerged, and formed the present-day reef. In the areas of Giofiros and Almiros the low topographic relief and muddy sediments act as indicators of a potential lagoon system behind the dune field.

The proposed DEM and shoreline position of the Ammoudara beach 6 ka ago agrees with findings from archeological excavation in the central Northern Crete. The sea level rise by $1.20 \mathrm{~m}$ between the Minoan Protopalatial and Neopalatial phase could be associated with a large seismic event that most likely occurred around 1700 BC [119]. The change by $1.45 \mathrm{~m}$ between the sea level stand of the Neopalatial phase $(-2.70 \pm 0.15 \mathrm{~m})$ and the sea level stand with un upper age dated to the fourth century BC $(-1.25 \pm 0.25 \mathrm{~m})$, would be either contemporary with the second destruction of the Minoan centers $(\sim 1450$ BC) or in one or more paroxysmal events between 1450 BC and 400 BC. After the Roman conquest of Crete and during the subsequent centuries, 35 earthquakes from moderate to large magnitude (MO 6.5 to 8.2), are reported in this region [121-126]. Particularly, the earthquake of 365 (MO 8.2), latter split the island and caused crustal uplift in western Crete. The tsunami triggered by this event struck the coasts of most parts of the Mediterranean basin [35,39,127]. Sea level indicators depict the submerged ancient coasts of Crete. The presence of submerged tidal notches and beach rocks observed also in the nearby coasts provide evidence for the existence of old shores [128]. The proximity of installations such as breakwaters, jetties, ship sheds or fish tanks provide sufficient sealevel indicators. Measurements of the emerged part with respect to the average sea level, the estimated time of construction and abandonment, as well as the evaluation of both the height and functional depth to the mean sea level play an important role in understanding mean sea level changes in correlation to archaeological remains [129]. In Sicily, the sluice gate of a sunken fish tank helped the archaeologists deduce that the functional height of the Roman quarry's floor (nowadays sunken) would be estimated around 0,60 m above sea level [130]. The reported rock-cut ship sheds and fish tanks from Crete are in the vicinity of coastal quarries. The fish tanks at Chersonissos, $35 \mathrm{~km}$ away from the study area, could be correlated with the beach rock quarry. The floors of three fish-tanks at Chersonissos arranged in a row, now lie between 1,95m and 2,20m below modern sea level $[83,131]$. To the north at Agia Pelagia, $10 \mathrm{~km}$ north from the study area, [132] noticed some hollow channels and some holes in the shape of tubes, which sometimes protruded up to $0,15 \mathrm{~m}$ from the surface of the sandstone. Those were interpreted as remnants of previous dunes that were covered with plants [132]. The same applies to the coastal quarry of Malia $40 \mathrm{~km}$ from Ammoudara [133,134]. Some of these holes could have been opened by the Minoans quarrymen, for the insertion of poles and wooden beams [134]. Moreover, in Amnisos $10 \mathrm{~km}$ east archeological findings of coastal infrastructures indicate a $-2 \mathrm{~m}$ sea level at $3500 \mathrm{BP}$ [135] (for locations in figure 12).

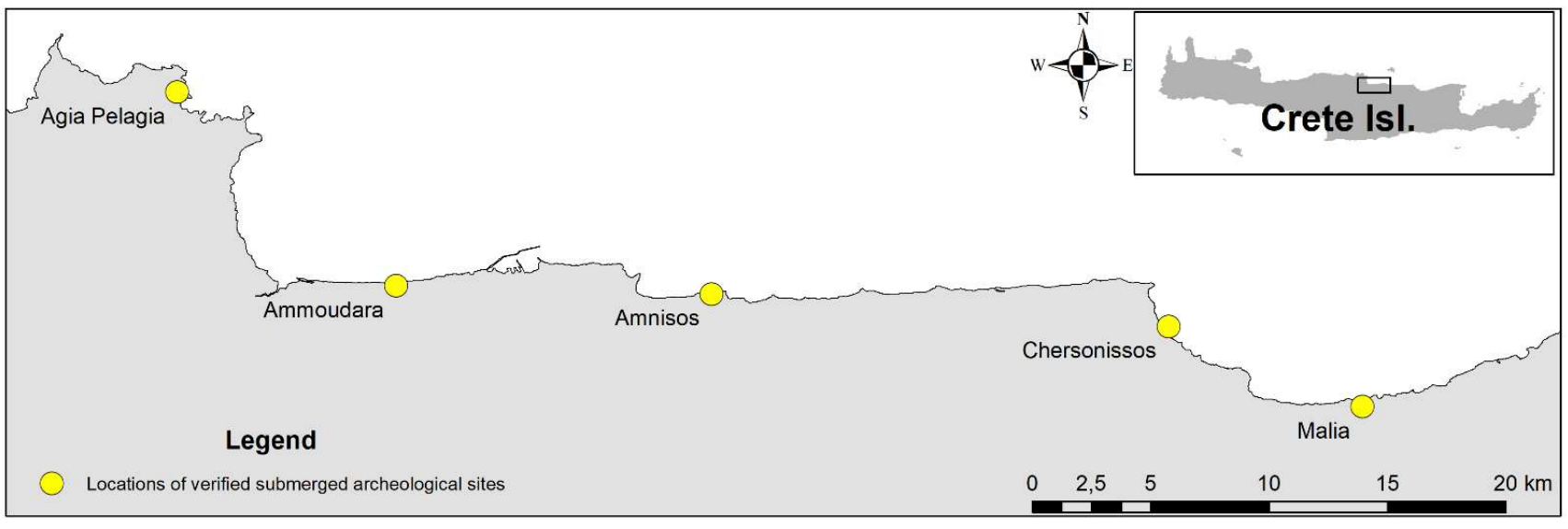

Figure 12. Locations of archeological Sea level indicators in the proximity of Ammoudara beach 
Similar approaches of proposing conceptual geomorphological evolution models were proposed for the coastal region of the Sylt Isl., a barrier island in the southern North Sea of North China that presented the sediment material sources during glacial and interglacial periods [136]. Moreover, in a case study in the Itapicuru coastal plain, north coast of Bahia State, paleoenvironmental information and OSL dating were used to define the possible geomorphological evolution scenario during the Upper-Middle Holocene of marine terraces and floodplain, where it was indicated a slow and gradual regressive phase that was responsible for the highest marine terrace's formation [137]. Additionally a reconstruction of Naples coast since the mid-Holocene by using geomorphological analysis based on historical sources; ancient pictures and maps; high-resolution digital terrain model (DTM) combined with iconographic researches allowed for reconstructing geomorphological map and proposed three new paleoenvironmental scenarios of the study area during the Holocene, deriving from the evaluation of the relative sea-level changes and vertical ground movements of volcano-tectonic origin [138].

When applying OSL dating in archaeology, one of the challenges is how to properly interpret the ages and their contexts. OSL could be used to date deposits that are related to otherwise defined cultural layers [139-141], or deposits that are directly associated with cultural material, where it essentially dates human disturbance of that sediment. Consequently, to assess the reliability of an OSL age, a detailed understanding of the archaeological context is especially critical to be able to evaluate whether enough of that disturbance had occurred to fully reset the luminescence signal. The archaeological site in the area near drills G2 and G2' is a well dated site which contains numerous archaeological features and ceramic artifacts [87]. Moreover, in the research drill G2' a small ceramic was found in the $6 \mathrm{~m}$ depth ( 4 from current sea level) [118]. The OSL samples, which came from drill G2 above and below the dated layer, were dated to $1.4 \pm$ $0.1 \mathrm{ka}$ at both 0.3 and $0.6 \mathrm{~m}$ depth. The OSL results date the disturbed sand deposit. It is not necessarily surprising that OSL ages are slightly older. Assuming the samples were disturbed by human activity, the probable forested setting, and the potential lack of complete sunlight exposure of the sand makes it likely that some residual signal may have been retained in the grains, causing some overestimation of the OSL age [142]. Also, it is possible that there was no more extensive human presence there and that the $\sim 2 \mathrm{ka}$ OSL ages may indicate some natural sand remobilization that occurred at that time. While localized dune formation cannot be discounted, it is not possible to fully interpret these dates without further archaeological testing as well as further OSL dating at the same depth in other parts of the Ammoudara dune field. This illustrates how important a broader archaeological and sedimentary context is for the interpretation of OSL data. Often, sparse artifact scatters are incorporated into sand deposits without clear indication of whether they are in their original context, or perhaps within a buried lag surface, making interpretation of OSL dates and their relationship with the original occupation time extremely difficult. Even if that is the case, careful examination of OSL data can provide insight into the conceptual development of a coastal landscape [109,143-145].

\section{Conclusions}

The puzzling scarcity of archaeological sites on the Ammoudara beach prompted an investigation into the chronology of the development of this dune field. Soil samples collected from the research were dated using Optically Stimulated Luminescence to refine the chronology of the area and assess the variability of ages with depth. The use of drilling in the dune field enabled the collection of samples from a $10 \mathrm{~m}$ long stratigraphic column and the capturing of the early stages of the dune formation (OSL ages $\sim 9.0-9.6 \mathrm{ka}$ ), while the OSL ages from $6 \mathrm{~m}$ depth represented the timing of its stabilization (OSL ages $~ 5-6$ $\mathrm{ka}$ ). The dune field appears to have formed relatively long before the bronze age and became stabilized with only localized episodes of dune reactivation occurring thereafter and mainly near river mouths based on the sediment texture. The shore-parallel reef in the Ammoudara coastal zone is a submerged beachrock that was formed during the upper 


\section{References}

Holocene [113]. Its current position, about $0.5 \mathrm{~m}$ below sea level, indicates a relative sea level rise of more than $0.5 \mathrm{~m}$; the latter has caused a coastline retreat of approximately 50 $\mathrm{m}$. During the last decade, the erosion rates have decreased and the beach zone of Ammoudara seems to be more stable, reaching a morphodynamics equilibrium with the nearshore hydrodynamic conditions. Luminescence dating of the aeolian deposits in the coastal area of Ammoudara yields ages ranging from the bronze age and older, suggesting that the coastal dunes in the area were accumulated during the past 10,000 years. The study also revealed that, at the depth of $6 \mathrm{~m}$ below the ground surface, sediments dated back as old as Bronze age. Whatever the extent of the more recent dune reactivation was in the study area, it was probably localized and not substantial enough to cause significant sand accumulation that would place archaeological deposits outside of the reach of standard proportionate methods. Since the geologic setting does not appear to preclude the archaeologists' access to potential resources, the sparse distribution pattern of human occupation on the Ammoudara Beach might be better explained by exploring cultural habitation choices of past populations. Overall, the landscape reconstruction suggests that geomorphologically, the area was rather different in the Bronze Age. Based on the archaeological and geomorphological findings, alluvial plain sediments seem to have been appropriate for agriculture since they were higher than sea level, while the location of shoreline is indicated approximately $200 \mathrm{~m}$ away from its current position. This can be also supported by the agricultural activities that are visible in the 1945 aerial photograph. Future work will need to address the depth to which OSL ages are adversely impacted by turbation due to wave and river processes.

1. Walsh, K. Sea-Level Change and Coastal Settlement - Human Engagements with Littoral Environments. In The Archaeology of Mediterranean Landscapes: Human-Environment Interaction from the Neolithic to the Roman Period, Walsh, K., Ed.; Cambridge University Press: Cambridge, 2013; pp. 30-67.

2. Foutrakis, P.M.; Anastasakis, G.; Piper, D.J.W. Chronology of Quaternary shoreline progradational sequences related to eustatic sea-level changes: Sedimentation and subsidence in Saronikos Gulf, Greece. Marine Geology 2020, 428, 106278, doi:https://doi.org/10.1016/j.margeo.2020.106278.

3. Pirazzoli, P.A. World atlas of Holocene sea-level changes / Paolo Antonio Pirazzoli ; assistant, Jean Pluet; Elsevier: Amsterdam ; New York, 1991.

4. Lambeck, K.; Bard, E.J.E.; Letters, P.S. Sea-level change along the French Mediterranean coast for the past 30 000 years. 2000, 175, 203-222.

5. Fairbridge, R. Holocene sea-level oscillations. In Proceedings of the Florilegium Florinis Dedicatum, 1981; pp. 131-141.

6. Pirazzoli, P.A. A review of possible eustatic, isostatic and tectonic contributions in eight late-Holocene relative sea-level histories from the Mediterranean area. Quaternary Science Reviews 2005, 24, 1989-2001, doi:http://dx.doi.org/10.1016/j.quascirev.2004.06.026.

7. Church, J.A.; Gregory, J.M.; Huybrechts, P.; Kuhn, M.; Lambeck, K.; Nhuan, M.T.; Qin, D.; Woodworth, P.L. Changes in Sea Level. In Climate Change 2001: The Scientific Basis, Ding, H.a., Ed.; Cambridge Univ. Press: Cambridge, 2001.

8. Lambeck, K. Late Pleistocene and Holocene sea-level change in Greece and south-western Turkey: a separation of eustatic, isostatic and tectonic contributions. Geophysical Journal International 1995, 122, 1022-1044, doi:10.1111/j.1365-246X.1995.tb06853.x.

9. Lambeck, K. The Earth's variable rotation: geophysical causes and consequences; Cambridge University Press: 2005.

10. IPCC. Chapter 5: Sea level rise. In Climate Change 2007, The Scientific Basis; http://www.ipcc.ch/pub, 2007. 
11. Lambeck, K.; Anzidei, M.; Antonioli, F.; Benini, A.; Esposito, A. Sea level in Roman time in the Central Mediterranean and implications for recent change. Earth and Planetary Science Letters 2004, 224, 563-575, doi:https://doi.org/10.1016/j.epsl.2004.05.031.

12. Fouache, E.; Dalongeville, R. Recent relative variations in the shorelines : a contrastive approach of the shores of Croatia and southern Turkey. In The Mediteranean World : Environment and History. Actes du Colloque Environmental Dynamics and History in Mediterraneans Areas, Fouache, E., Ed.; Elsevier Paris: 2003; pp. 467-478.

13. Vouvalidis, K.; Syrides, G.; Albanakis, K.J.Z.f.G. Holocene morphology of the Thessaloniki Bay: impact of sea level rise. 2005, 137, 147-158.

14. Pavlopoulos, K.; Kapsimalis, V.; Theodorakopoulou, K.; Panagiotopoulos, I.P. Vertical displacement trends in the Aegean coastal zone (NE Mediterranean) during the Holocene assessed by geo-archaeological data. The Holocene 2011, 22, 717-728, doi:10.1177/0959683611423683.

15. Ghilardi, M.; Vacchi, M.; Currás, A.; Müller Celka, S.; Theurillat, T.; Lemos, I.; Pavlopoulos, K.J.Q. Geoarchaeology of coastal landscapes along the south Euboean gulf (Euboea Island, Greece) during the Holocene. 2018.

16. Vött, A. Relative sea level changes and regional tectonic evolution of seven coastal areas in NW Greece since the mid-Holocene. Quaternary Science Reviews 2007, 26, 894-919, doi:https://doi.org/10.1016/j.quascirev.2007.01.004.

17. Lambeck, K.; Purcell, A.J.Q.S.R. Sea-level change in the Mediterranean Sea since the LGM: model predictions for tectonically stable areas. 2005, 24, 1969-1988.

18. Mourtzas, N.; Kolaiti, E.; Anzidei, M. Vertical land movements and sea level changes along the coast of Crete (Greece) since Late Holocene. Quaternary International 2016, 401, 43-70, doi:https://doi.org/10.1016/j.quaint.2015.08.008.

19. Mercier, J.; Bousquet; Dellibasis, N.; Drakopoulos, I.; Keraudren, B.; lemeille, F.; Sorel, D. Déformations en compression dans le Quaternaire des rivages ioniens (Céphalonie, Grèce). Données néotectoniques et sismiques. Comptes rendus de l'Académie des sciences. 1972, C. R. Acad. Sci. Paris, 2007-2010.

20. Mercier, J.; Angelier, J.; Delibassis, N.; Gerard, P.; Kerdiles, Y.J.C.e.r.A.S.d.l.T., Pont-a-Mousson. Les déformations plio-quaternaires en extension en Crète méridionale (lerapetra, Grèce). 1974.

21. Sorel, D. Etude neotectonique dans l'arc egeen externe occidental: les iles ioniennes de Kephallinia et Zakinthos et l'Elide occidentale. Université de Paris XI, 1976.

22. Angelier, J.; Lybéris, N.; Le Pichon, X.; Barrier, E.; Huchon, P. The tectonic development of the hellenic arc and the sea of crete: A synthesis. Tectonophysics 1982, 86, 159-196, doi:https://doi.org/10.1016/0040-1951(82)90066-X.

23. Angelier, J. Determination of the mean principal directions of stresses for a given fault population. Tectonophysics 1979, 56, T17-T26, doi:http://dx.doi.org/10.1016/0040-1951(79)90081-7.

24. Fytrolakis, N.J.H.t. The geological structure of Crete. Problems, observations and conclusions. $1980,143$.

25. Meulenkamp, J.; Jonkers, A.; Spaak, P.P., VI Colloquium. . Late Miocene to early Pliocene development of Crete. In Proceedings of the VI Colloquium Geology of the Aegean Region, Athens, 1977; pp. 137 - 149.

26. Meulenkamp, J.E.; van der Zwaan, G.J.; van Wamel, W.A. On late miocene to recent vertical motions in the Cretan segment of the Hellenic arc. Tectonophysics 1994, 234, 53-72, doi:http://dx.doi.org/10.1016/00401951(94)90204-6.

27. Peters, J.M. Neogene and Quaternary vertical tectonics in the south Hellenic arc and their effect on concurrent sedimentation processes; Gua: 1985. 
28. Mourtzas, N. Tectonic movement of the coasts of eastern Crete during the Quaternary. Ph. D. thesis, Technical University of Athens, 480pp.(In Greek), 1990.

29. Kelletat, D. Perspectives in coastal geomorphology of western Crete, Greece. Zeitschrift fur Geomorphologie, Supplementband 1996, 102, 1-19.

30. Peterek, A.; Schwarze, J. Architecture and Late Pliocene to recent evolution of outer-arc basins of the Hellenic subduction zone (south-central Crete, Greece). Journal of Geodynamics 2004, 38, 19-55, doi:https://doi.org/10.1016/j.jog.2004.03.002.

31. Wegmann, K.W. Tectonic geomorphology above Mediterranean subduction zones: northeastern Apennines of Italy and Crete, Greece; Lehigh University: 2008.

32. Tiberti, M.M.; Basili, R.; Vannoli, P. Ups and downs in western Crete (Hellenic subduction zone). Scientific Reports 2014, 4, 5677, doi:10.1038/srep05677.

33. Zachariasse, W.J.; van Hinsbergen, D.J.; Fortuin, A.R. Formation and fragmentation of a late Miocene supradetachment basin in central Crete: Implications for exhumation mechanisms of high-pressure rocks in the Aegean forearc. Basin Research 2011, 23, 678-701, doi:DOI: 10.1029/2007JB005382; .

34. Ott, R.F.; Gallen, S.F.; Wegmann, K.W.; Biswas, R.H.; Herman, F.; Willett, S.D. Pleistocene terrace formation, Quaternary rock uplift rates and geodynamics of the Hellenic Subduction Zone revealed from dating of paleoshorelines on Crete, Greece. Earth and Planetary Science Letters 2019, 525, 115757, doi:https://doi.org/10.1016/j.eps1.2019.115757.

35. Stiros, S.C.J.Q.I. The 8.5+ magnitude, AD365 earthquake in Crete: Coastal uplift, topography changes, archaeological and historical signature. 2010, 216, 54-63.

36. McCoy, F.W.; Heiken, G.J.P.; Geophysics, A. Tsunami generated by the Late Bronze age eruption of Thera (Santorini), Greece. 2000, 157, 1227-1256.

37. Sigurdsson, H.; Carey, S.; Alexandri, M.; Vougioukalakis, G.; Croff, K.; Roman, C.; Sakellariou, D.; Anagnostou, C.; Rousakis, G.; Ioakim, C.J.E., Transactions American Geophysical Union. Marine investigations of Greece's Santorini volcanic field. 2006, 87, 337-342.

38. Bruins, H.J.; MacGillivray, J.A.; Synolakis, C.E.; Benjamini, C.; Keller, J.; Kisch, H.J.; Klügel, A.; Van Der Plicht, J.J.J.o.A.S. Geoarchaeological tsunami deposits at Palaikastro (Crete) and the Late Minoan IA eruption of Santorini. 2008, 35, 191-212.

39. Flouri, E.T.; Kalligeris, N.; Alexandrakis, G.; Kampanis, N.A.; Synolakis, C.E. Application of a finite difference computational model to the simulation of earthquake generated tsunamis. Applied Numerical Mathematics 2013, 67, 111-125, doi:http://dx.doi.org/10.1016/j.apnum.2011.06.003.

40. Alexandrakis, G.; Karditsa, A.; Poulos, S.; Ghionis, G.; Kampanis, N. An assessment of the vulnerability to erosion of the coastal zone due to a potential rise of sea level: The case of the Hellenic Aegean coast. In Encyclopedia of Life Support Systems (EOLSS). Developed under the Auspices of the UNESCO, Sydow, A., Ed.; Eolss Publishers: Oxford, UK, 2010; Volume 1.

41. Alexandrakis, G.; Ghionis, G.; Poulos, S.E.; Kampanis, N.A. Greece. In Coastal Erosion and Protection in Europe: A Comprehensive Overview, Pranzini, E., Williams, A., Eds.; Earthscan London, 2013; pp. 355-377.

42. Alexandrakis, G.; Poulos, S.E. An holistic approach to beach erosion vulnerability assessment. Sci. Rep. 2014, 4, doi:10.1038/srep06078.

43. Cooper, J.A.G. Beachrock formation in low latitudes: implications for coastal evolutionary models. Marine Geology 1991, 98, 145-154. 
44. Neumeier, U. Experimental modelling of beachrock cementation under microbial influence. Sedimentary Geology 1999, 126, 35-46.

45. Kneale, D.; Viles, H.A. Beach cement: incipient CaCO3-cemented beachrock development in the upper intertidal zone, North Uist, Scotland. Sedimentary Geology 2000, 132, 165-170.

46. Moore, C.H. Intertidal carbonate cementation Grand Cayman, West Indies. Journal of Sedimentary Petrology 1973, 43, 591-602.

47. Beier, J.A. Diagenesis of Quaternary Bahamian beachrock: petrographic and isotopic evidence. Journal of Sedimentary Petrology 1985, 55, 755-761.

48. Chowdhury, S.Q.; Fazlul Haq, A.T.M.; Hasan, K. Beachrock in St. Martin's Island, Bangladesh: Implication of Sea Level Changes on Beachrock cementation. Marine Geodesy 1997, 20, 89- 104.

49. Plomaritis, T. Morphology and geochemistry of the beachrocks of Sifnos (Greece). MSc University of Southampton, 1999.

50. Holail, H.; Rashed, M. Stable isotopic composition of carbonate-cemented recent beachrock along the Mediterranean and the Red Sea coasts of Egypt. Marine Geology 1992, 106, 141-148.

51. Tatumi, S.H.; Kowata, E.A.; Gozzi, G.; Kassab, L.R.P.; Suguio, K.; Barreto, A.M.F.; Bezerra, F.H.R. Optical dating results of beachrock, eolic dunes and sediments applied to sea-level changes study. Journal of Luminescence 2003, 102-103, 562-565.

52. Calvet, F.; Cabrera, M.C.; Carracedo, J.C.; Mangas, J.; Perez-Torrado, F.J.; Recio, C.; Trave, A. Beachrocks from the island of La Palma (Canary Islands, Spain). Marine Geology 2003, 197, 75-93.

53. Pavlopoulos, K.; Karimpolis, E.; Karkanas, P.; Parlama, L.; Manos, I.; Triantafilou, M.; Theochari, M. Geomorphological evolution of the Pamalari bay (NE Skyros Island) during the Upper Holocene. In Proceedings of the 10th International Conference of the Greek Geological Society, Thessaloniki, 2004.

54. Poulos, S.E.; Ghionis, G.; Verykiou, E.; Roussakis, G.; Sakellariou, D.; Karditsa, A.; Alexandrakis, G.; Petrakis, S.; Sifnioti, D.; Panagiotopoulos, I.P.; et al. Hydrodynamic, neotectonic and climatic control of the evolution of a barrier beach in the microtidal environment of the NE Ionian Sea (eastern Mediterranean). Geo-Marine Letters 2015, 35, 37-52, doi:10.1007/s00367-014-0390-2.

55. Vousdoukas, M.I.; Velegrakis, A.F.; Plomaritis, T.A. Beachrock occurrence, characteristics, formation mechanisms and impacts. Earth-Science Reviews 2007, 85, 23-46.

56. Hopley, D. Beachrock as a sea-level indicator. In Sea-level Research: a manual for the collection and evaluation of data, van der Plassche, O., Ed.; Geo Books: Norwich, 1986; pp. 157- 173.

57. Yaltirak, C.; Sakinc, M.; Aksu, A.E.; Hiscott, R.N.; Galleb, B.; Ulgen, U.B. Late Pleistocene uplift history along the southwestern Marmara Sea determined from raised coastal deposits and global sea-level variations. Marine Geology 2002, 190, 283-305.

58. Bezerra, F.H.R.; Barreto, A.M.F.; Suguio, K. Holocene sea-level history on the Rio Grande do Norte State coast, Brazil. Marine Geology 2003, 196, 73-89.

59. Falkenroth, M.; Schneider, B.; Hoffmann, G. Beachrock as sea-level indicator - A case study at the coastline of Oman (Indian Ocean). Quaternary Science Reviews 2019, 206, 81-98, doi:https://doi.org/10.1016/j.quascirev.2019.01.003.

60. Rovere, A.; Raymo, M.E.; Vacchi, M.; Lorscheid, T.; Stocchi, P.; Gómez-Pujol, L.; Harris, D.L.; Casella, E.; O'Leary, M.J.; Hearty, P.J. The analysis of Last Interglacial (MIS 5e) relative sea-level indicators: Reconstructing sea-level in a warmer world. Earth-Science Reviews 2016, 159, 404-427, doi:https://doi.org/10.1016/j.earscirev.2016.06.006. 
61. Karkani, A.; Evelpidou, N.; Vacchi, M.; Morhange, C.; Tsukamoto, S.; Frechen, M.; Maroukian, H. Tracking shoreline evolution in central Cyclades (Greece) using beachrocks. Marine Geology 2017, 388, 25-37, doi:https://doi.org/10.1016/j.margeo.2017.04.009.

62. Desruelles, S.; Fouache, É.; Ciner, A.; Dalongeville, R.; Pavlopoulos, K.; Kosun, E.; Coquinot, Y.; Potdevin, J.-L. Beachrocks and sea level changes since Middle Holocene: Comparison between the insular group of MykonosDelos-Rhenia (Cyclades, Greece) and the southern coast of Turkey. Global and Planetary Change 2009, 66, 19-33, doi:10.1016/j.gloplacha.2008.07.009.

63. Fairbridge, R.W.; Johnson, D.L. Eolianite. In The encyclopedia of sedimentology Fairbridge, R., . W.,, Bourgeois, J., Eds.; Dowden Hutchinson Ross: Stroudsburg Pennsylvania, 1978; pp. 279-282.

64. Bateman, M.D.; Holmes, P.J.; Carr, A.S.; Horton, B.P.; Jaiswal, M.K. Aeolianite and barrier dune construction spanning the last two glacial-interglacial cycles from the southern Cape coast, South Africa. Quaternary Science Reviews 2004, 23, 1681-1698, doi:https://doi.org/10.1016/j.quascirev.2004.02.001.

65. Jacob, T.; Wahr, J.; Pfeffer, W.T.; Swenson, S. Recent contributions of glaciers and ice caps to sea level rise. Nature 2012, 482, 514-518, doi:10.1038/nature10847.

66. Mauz, B.; Hijma, M.P.; Amorosi, A.; Porat, N.; Galili, E.; Bloemendal, J. Aeolian beach ridges and their significance for climate and sea level: Concept and insight from the Levant coast (East Mediterranean). EarthScience Reviews 2013, 121, 31-54, doi:https://doi.org/10.1016/j.earscirev.2013.03.003.

67. Mauz, B.; Vacchi, M.; Green, A.; Hoffmann, G.; Cooper, A. Beachrock: A tool for reconstructing relative sea level in the far-field. Marine Geology 2015, 362, 1-16, doi:https://doi.org/10.1016/j.margeo.2015.01.009.

68. Hearty, P.J.; Pascal, K. The Stratigraphy and Surficial Geology of New Providence and Surrounding Islands, Bahamas. Journal of Coastal Research 1997, 13, 798-812.

69. Murray-Wallace, C.V.; Bourman, R.P.; Prescott, J.R.; Williams, F.; Price, D.M.; Belperio, A.P. Aminostratigraphy and thermoluminescence dating of coastal aeolianites and the later Quaternary history of a failed delta: The River Murray mouth region, South Australia. Quaternary Geochronology 2010, 5, 28-49, doi:https://doi.org/10.1016/j.quageo.2009.09.011.

70. Pye, K.; Tsoar, H. Aeolian sand and sand dunes; Springer Science \& Business Media: 2008.

71. Pye, K.; Tsoar, H. The Formation of Sand Seas and Dune Fields. In Aeolian Sand and Sand Dunes; Springer Berlin Heidelberg: Berlin, Heidelberg, 2009; pp. 141-173.

72. Andreucci, S.; Clemmensen, L.B.; Murray, A.S.; Pascucci, V.J.Q.I. Middle to late Pleistocene coastal deposits of Alghero, northwest Sardinia (Italy): Chronology and evolution. 2010, 222, 3-16.

73. Frechen, M.; Neber, A.; Tsatskin, A.; Boenigk, W.; Ronen, A. Chronology of Pleistocene sedimentary cycles in the Carmel Coastal Plain of Israel. Quaternary International 2004, 121, 41-52, doi:https://doi.org/10.1016/j.quaint.2004.01.022.

74. Rodríguez-Vidal, J.; Finlayson, G.; Finlayson, C.; Negro, J.J.; Cáceres, L.M.; Fa, D.A.; Carrión, J.S. Undrowning a lost world - The Marine Isotope Stage 3 landscape of Gibraltar. Geomorphology 2013, 203, 105-114, doi:https://doi.org/10.1016/j.geomorph.2013.02.015.

75. Fornós, J.J.; Clemmensen, L.B.; Gómez-Pujol, L.; Murray, A.S. Late Pleistocene carbonate aeolianites on Mallorca, Western Mediterranean: a luminescence chronology. Quaternary Science Reviews 2009, 28, 2697-2709, doi:https://doi.org/10.1016/j.quascirev.2009.06.008.

76. Bardají, T.; Goy, J.L.; Zazo, C.; Hillaire-Marcel, C.; Dabrio, C.J.; Cabero, A.; Ghaleb, B.; Silva, P.G.; Lario, J. Sea level and climate changes during OIS 5e in the Western Mediterranean. Geomorphology 2009, 104, 22-37, doi:https://doi.org/10.1016/j.geomorph.2008.05.027. 
77. del Valle Villalonga, L.; Timar-Gabor, A.; Fornós, J.J. Geomorphological Processes and Environmental Interpretation at Espalmador islet (Western Mediterranean). 2019, 7, 144.

78. Vacher, H.; Hearty, P.; Rowe, M.; Curran, H.; White, B.J.S.P.-G.S.O.A. Stratigraphy of Bermuda: nomenclature, concepts, and status of multiple systems of classification. 1995, 271-294.

79. Boekschoten, G.J. Beachrock at Limani Chersonisos, Crete. Geologie en Mijnbouw 1962, 41, 3-7.

80. Gaki-Papanastassiou, K.; Karymbalis, E.; Papanastassiou, D.; Maroukian, H. Quaternary marine terraces as indicators of neotectonic activity of the Ierapetra normal fault SE Crete (Greece). Geomorphology 2009, 104, 3846, doi:https://doi.org/10.1016/j.geomorph.2008.05.037.

81. Dermitzakis, M.; Michail, C.; Mpasiakos, G.; Tripolitsioutou, F. Contricution to the absolute dating of beachrock by the means of the Thermoluminescence technique. (in Greek with English abstract). In Proceedings of the 4th National Symposium on Oceanography and Fisheries, Rhodes Island, April 1993, 1993 pp. 267-259.

82. Kelletat, D. Zonality of Modern Coastal Processes and Sea-Level Indicators. Palaeogeography, Palaeoclimatology, Palaeoecology 1988, 68, 219-230.

83. Mourtzas, N.D. Fish tanks of eastern Crete (Greece) as indicators of the Roman sea level. Journal of Archaeological Science 2012, 39, 2392-2408, doi:http://dx.doi.org/10.1016/j.jas.2012.02.006.

84. Hatzidakis, I. Minoikoi tafoi stin Kriti (in Greek). Archaiologikon Deltion 1918, 4, 45-87.

85. Evans, A.J. The Palace of Minos at Knossos; Macmillan: LOndon, 1928; Volume 2, p. 232.

86. Hadzi-Vallianos, D. Prefecture of Heraklion, Gazi - Ammoudara. Archaiologikon Deltion 1979, 34, $384-385$.

87. Athanasaki, K. A coastal Neopalatial settlement in Ammoudara Heraklion: A preliminary approach'. In Proceedings of the Archaeological Work in Crete, Proceedings of the Third Meeting, , Rethymnon 2015; pp. 271280.

88. Murray, A.S.; Clemmensen, L.B. Luminescence dating of Holocene aeolian sand movement, Thy, Denmark. Quaternary Science Reviews 2001, 20, 751-754, doi:https://doi.org/10.1016/S0277-3791(00)00061-5.

89. Banerjee, D.; Murray, A.S.; Bøtter-Jensen, L.; Lang, A.J.R.m. Equivalent dose estimation using a single aliquot of polymineral fine grains. 2001, 33, 73-94.

90. Clemmensen, L.B.; Bjørnsen, M.; Murray, A.; Pedersen, K.J.S.G. Formation of aeolian dunes on Anholt, Denmark since AD 1560: A record of deforestation and increased storminess. 2007, 199, 171-187.

91. Murray, A.; Clemmensen, L. Luminescence dating of Holocene aeolian sand movement, Thy, Denmark. Quaternary Science Reviews 2001, 20, 751-754.

92. Roberts, R.G.; Galbraith, R.; Yoshida, H.; Laslett, G.; Olley, J.M.J.R.M. Distinguishing dose populations in sediment mixtures: a test of single-grain optical dating procedures using mixtures of laboratory-dosed quartz. 2000, 32, 459-465.

93. Kitis, G.; Polymeris, G.; Pagonis, V.; Tsirliganis, N.J.R.m. Anomalous fading of OSL signals originating from very deep traps in Durango apatite. 2013, 49, 73-81.

94. Duller, G.A.T. Recent developments in luminescence dating of Quaternary sediments. Progress in Physical Geography: Earth and Environment 1996, 20, 127-145, doi:10.1177/030913339602000201.

95. Jain, C.; Singhal, D.; Sharma, M.J.J.o.h.m. Adsorption of zinc on bed sediment of River Hindon: adsorption models and kinetics. 2004, 114, 231-239.

96. Porat, N.; Amit, R.; Enzel, Y.; Zilberman, E.; Avni, Y.; Ginat, H.; Gluck, D.J.J.o.A.E. Abandonment ages of alluvial landforms in the hyperarid Negev determined by luminescence dating. 2010, 74, 861-869.

97. Bowman, D.; Korjenkov, A.; Porat, N.J.S.G. Late-Pleistocene seismites from Lake Issyk-Kul, the tien shan range, Kyrghyzstan. 2004, 163, 211-228. 
98. Choi, J.; Murray, A.; Cheong, C.; Hong, D.; Chang, H.J.Q.S.R. The resolution of stratigraphic inconsistency in the luminescence ages of marine terrace sediments from Korea. 2003, 22, 1201-1206.

99. Huntley, D.J.; Godfrey-Smith, D.I.; Thewalt, M.L.W. Optical dating of sediments. Nature 1985, 313, 105-107, doi:10.1038/313105a0.

100. Jacob, J.; Gama, C.; Salgado, R.; Liu, J.T.; Silva, A. Shadowing Effects on Beach Morphodynamics during Storm Events on Tróia-Sines Embayed Coast, Southwest Portugal. Journal of Coastal Research 2009, 73-77, doi:10.2307/25737540.

101. Madsen, A.T.; Murray, A.S. Optically stimulated luminescence dating of young sediments: A review. Geomorphology 2009, 109, 3-16, doi:https://doi.org/10.1016/j.geomorph.2008.08.020.

102. Tsakalos, E.; Athanassas, C.; Tsipas, P.; Triantaphyllou, M.; Geraga, M.; Papatheodorou, G.; Filippaki, E.; Christodoulakis, J.; Kazantzaki, M.J.A.; Sciences, A. Luminescence geochronology and paleoenvironmental implications of coastal deposits of southeast Cyprus. 2018, 10, 41-60.

103. Nian, X.; Zhang, W.; Qiu, F.; Qin, J.; Wang, Z.; Sun, Q.; Chen, J.; Chen, Z.; Liu, N.J.Q.G. Luminescence characteristics of quartz from Holocene delta deposits of the Yangtze River and their provenance implications. 2019, 49, 131-137.

104. Aitken, M.J. Introduction to optical dating: the dating of Quaternary sediments by the use of photon-stimulated luminescence; Clarendon Press: 1998.

105. Roberts, R.; Bird, M.; Olley, J.; Galbraith, R.; Lawson, E.; Laslett, G.; Yoshida, H.; Jones, R.; Fullagar, R.; Jacobsen, G.; et al. Optical and radiocarbon dating at Jinmium rock shelter in northern Australia. Nature 1998, 393, 358362, doi:10.1038/30718.

106. Bristow, C.S.; Duller, G.; Lancaster, N.J.G. Age and dynamics of linear dunes in the Namib Desert. 2007, 35, 555558.

107. Costas, S.; Ferreira, Ó.; Plomaritis, T.A.; Leorri, E.J.S.r. Coastal barrier stratigraphy for Holocene high-resolution sea-level reconstruction. 2016, 6, 1-12.

108. Tamura, T.; Oliver, T.; Cunningham, A.C.; Woodroffe, C.D.J.G.R.L. Recurrence of extreme coastal erosion in SE Australia beyond historical timescales inferred from beach ridge morphostratigraphy. 2019, 46, 4705-4714.

109. Wang, F.; Zhang, W.; Nian, X.; Ge, C.; Zhao, X.; Cheng, Q.; Chen, J.; Hutchinson, S.M.J.T.H. Refining the lateHolocene coastline and delta development of the northern Yangtze River delta: Combining historical archives and OSL dating. 2019, 29, 1439-1449.

110. Fassoulas, C. The tectonic development of a Neogene basin at the leading edge of the active European margin: the Heraklion basin, Crete, Greece. Journal of Geodynamics 2001, 31, 49-70, doi:http://dx.doi.org/10.1016/S02643707(00)00017-X.

111. Tsimplis, M.N. Tidal oscillations in the Aegean and Ionian Seas. Estuarine, Coastal and Shelf Science 1994, 39, 201208.

112. Soukissian, T.; Hatzinaki, M.; Korres, G.; Papadopoulos, A.; Kallos, G.; Anadranistakis, E. Wind and Wave Atlas of the Hellenic Seas; Hellenic Centre for Marine Research Publ.: Athens, 2007.

113. Alexandrakis, G.; Ghionis, G.; Poulos, S. The Effect of Beach Rock Formation on the Morphological Evolution of a Beach. The Case Study of an Eastern Mediterranean Beach: Ammoudara, Greece. Journal of Coastal Research 2013,47-59, doi:10.2112/SI_69_5.

114. Folk, R.L. Petrology of the Sedimentary Rocks; Hemphill Publishing Company: Austin, Texas, U.S.A, $1980 ;$ p. 182.

115. Murray, A.S.; Wintle, A.G. Luminescence dating of quartz using an improved single-aliquot regenerative-dose protocol. Radiation Measurements 2000, 32, 57-73, doi:https://doi.org/10.1016/S1350-4487(99)00253-X. 
116. Aitken, M.J. Thermoluminescence dating; Academic Press: London, 1985.

117. Himmelstoss, E.A.; Henderson, R.E.; Kratzmann, M.G.; Farris, A.S. Digital Shoreline Analysis System (DSAS) version 5.0 user guide; 2018-1179; Reston, VA, 2018.

118. Alexandrakis, G.; Athanasaki, K.; Kampanis, N. Towards a GIS reconstruction of the Ammoudara coastal landscape, integrating archaeological evidence and geomorphological data. In Proceedings of the 2nd Conference on Computer Applications and Quantitative Methods in Archaeology Greek Chapter, Athens, 2016, 2016; pp. 45-50.

119. Pareschi, M.T.; Favalli, M.; Boschi, E. Impact of the Minoan tsunami of Santorini: Simulated scenarios in the eastern Mediterranean. 2006, 33, doi:https://doi.org/10.1029/2006GL027205.

120. Ashmore, W.J.A.c.t.s.a. Social archaeologies of landscape. 2004, 255-271.

121. Papazachos, V. The earthquakes of Greece; Editions Ziti: 1997.

122. Di Vita, A. Archaeologists and earthquakes: the case of 365 A.D. 1995 1995, 38, doi:10.4401/ag-4097 \%J Annals of Geophysics.

123. Di Vita, A. Earthquakes and civil life at Gortyn (Crete) in the period between Justinian and Constant II (6-7th century AD). Archaeoseismology 1996, 7, 45-50.

124. Spyropoulos, P.J.A.D. Chronicle of the Earthquakes of Greece from Antiquity until Today. 1997.

125. Ambraseys, N. Earthquakes in the Mediterranean and Middle East: a multidisciplinary study of seismicity up to 1900; Cambridge University Press: 2009.

126. Papadopoulos, G. A seismic history of Crete; 2011; Volume 65.

127. Guidoboni, E.; Comastri, A. The large earthquake of 8 August 1303 in Crete: seismic scenario and tsunami in the Mediterranean area. Journal of Seismology 1997, 1, 55-72, doi:10.1023/A:1009737632542.

128. Pirazzoli, P.; Evelpidou, N. Tidal notches: A sea-level indicator of uncertain archival trustworthiness. Palaeogeography, Palaeoclimatology, Palaeoecology 2013, 369, 377-384, doi:10.1016/j.palaeo.2012.11.004.

129. Auriemma, R.; Solinas, E. Archaeological remains as sea level change markers: A review. Quaternary International 2009, 206, 134-146, doi:10.1016/j.quaint.2008.11.012.

130. Scicchitano, G.; Lo Presti, V.; Spampinato, C.; Gasparo Morticelli, M.; Antonioli, F.; Auriemma, R.; Ferranti, L.; Monaco, C. Millstones as indicators of relative sea-level changes in northern Sicily and southern Calabria coastlines, Italy. Quaternary International 2011, 92-104, doi:10.1016/j.quaint.2010.08.019.

131. Leatham, J.; Hood, S. Sub-Marine Exploration in Crete, 1955. The Annual of the British School at Athens 1958, 53/54, 263-280.

132. Epting, M. Geologie der östlichen Talea Ori, Kreta. Freiburg, 1969.

133. Shaw, J.W.; cretese, U.d.C.C.d.a. Minoan Architecture: Materials and Techniques; Bottega d'Erasmo: 2009.

134. Guest-Papamanoli, A. Les carrières de grès dunaire à Malia Bulletin de Correspondance Hellénique 1989, 113-1, 113-122.

135. Mouslopoulou, V.; Begg, J.; Nicol, A.; Oncken, O.; Prior, C. Formation of Late Quaternary paleoshorelines in Crete, Eastern Mediterranean. Earth and Planetary Science Letters 2015, 431, 294-307, doi:https://doi.org/10.1016/j.epsl.2015.09.007.

136. Tian, S.; Sun, J.; Lü, L.; Cao, M.; Zhang, Z.; Lü, T. Optically stimulated luminescence dating of late Quaternary loess deposits in the coastal region of North China: Provenance and paleoclimatic implications. Quaternary Science Reviews 2019, 218, 160-177, doi:https://doi.org/10.1016/j.quascirev.2019.06.022.

137. Lima, K.C.; Perez Filho, A. EVOLUÇÃO GEOMORFOLÓGICA DE PLANÍCIES COSTEIRAS NO HOLOCENO \%J Mercator (Fortaleza). 2020, 19. 
138. Mattei, G.; Aucelli, P.P.C.; Caporizzo, C.; Rizzo, A.; Pappone, G. New Geomorphological and Historical Elements on Morpho-Evolutive Trends and Relative Sea-Level Changes of Naples Coast in the Last 6000 Years. 2020, 12, 2651.

139. Bueno, L.; Feathers, J.; Blasis, P. The formation process of a paleoindian open-air site in Central Brazil: Integrating lithic analysis, radiocarbon and luminescence dating. Journal of Archaeological Science 2013, 40, 190203, doi:10.1016/j.jas.2012.06.026.

140. Sommerville, A.A.; Hansom, J.; Sanderson, D.C.W.; Housley, R. Optically stimulated luminescence dating of large storm events in Northern Scotland. Quaternary Science Reviews 2003, 22, 1085-1092, doi:10.1016/S02773791(03)00057-X.

141. Sommerville, A.A.; Hansom, J.D.; Housley, R.A.; Sanderson, D.C.W. Optically stimulated luminescence (OSL) dating of coastal aeolian sand accumulation in Sanday, Orkney Islands, Scotland. 2007, 17, 627-637, doi:10.1177/0959683607078987.

142. Bateman, M.D.; Boulter, C.H.; Carr, A.; Frederick, C.; Peter, D.; Wilder, M. Preserving the palaeoenvironmental record in Drylands: Bioturbation and its significance for luminescence-derived chronologies. Sedimentary Geology 2007, 195, 5-19, doi:10.1016/j.sedgeo.2006.07.003.

143. Schokker, J.; Cleveringa, P.; Murray, A. Palaeoenvironmental reconstruction and OSL dating of terrestrial Eemian deposits in the southeastern Netherlands. Journal of Quaternary Science 2004, 19, 193-202, doi:10.1002/jqs.808.

144. Dörschner, N.; Reimann, T.; Wenske, D.; Lüthgens, C.; Tsukamoto, S.; Frechen, M.; Böse, M. Reconstruction of the Holocene coastal development at Fulong Beach in north-eastern Taiwan using optically stimulated luminescence (OSL) dating. Quaternary International 2012, 263, 3-13, doi:https://doi.org/10.1016/j.quaint.2011.12.009.

145. Shtienberg, G.; Dix, J.K.; Roskin, J.; Waldmann, N.; Bookman, R.; Bialik, O.M.; Porat, N.; Taha, N.; Sivan, D. New perspectives on coastal landscape reconstruction during the Late Quaternary: A test case from central Israel. Palaeogeography, Palaeoclimatology, Palaeoecology 2017, 468, 503-519, doi:https://doi.org/10.1016/j.palaeo.2016.12.045. 